Historic, Archive Document

Do not assume content reflects current scientific knowledge, policies, or practices. 



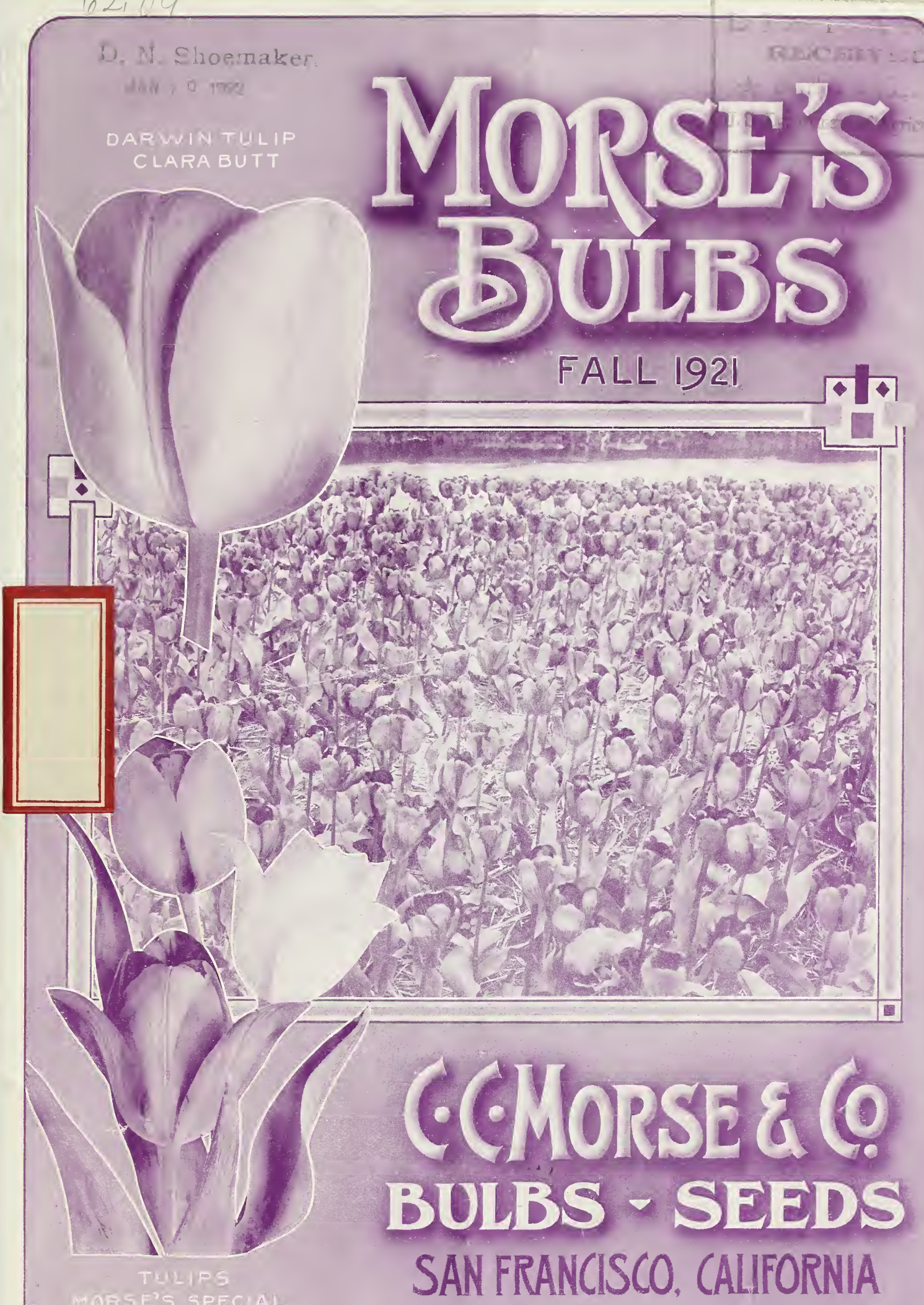




\section{Morse's Bulbs}

\section{GENERAL CULTURAL DIRECTIONS FOR BULBS}

Outdoor planting should be done early in the fall to secure healthy plants, vigorous foliage and beautiful flowers Set the bulbs so that there is earth above them to their own depth. This is a good rule. Do not overcrowd; 3 to 4 inches apart for small bulbs such as Crocus, Snowdrops, Ranunculus, etc.; 6-7 inches for Anemones, Jonquils, Tulips, Iris, Freesias; 7-9 inches for Hyacinths and Narcissus; 18 to 27 inches for Lilies.

\section{Non-Warranty}

Most of the failures with seeds, plants and bulbs are due to causes entirely beyond our control, such as unfavorable weather, too deep and too shallow plantings, slugs, ete., therefore C. C. Morse \& Co. give no warranty, express or implied, as to description, purity, productiveness, or any other matter of any seeds, plants, bulbs, etc., they send out, and will be in no way responsible for the crop; if the purchaser does not accept the goods on these terms they are to be returned to us at once.

We wish to remind you of the few usual requests which help us so much in our business:

\section{Please Order Early}

The best time is just as soon as this catalogue reaches you. The bulbs niay not have arrived by then, but your order will be given immediate attention, and be filled just as soon as the stock arrives. At the first of the season there are no sorts sold out, and, besides, the bulbs flower much better when planted early.

\section{Name and Address}

Please be sure to write plainly your full name and address, when sending us your order and remittance. Send also the name of the nearest express office, if bulbs are to come that way, when it differs from the postoffice. We send bulbs by express unless postage for the different sorts as shown in the catalogue accompanies the order.

\section{Morse's Bulbs are the very finest grade}

DIRECTIONS for pot growing and foreing. The bulbs must be unpacked as soon as received and should be potted at once, as good flowering results depend upon a thorough root growth. This can be obtained by early potting of the bulbs. Use old pots for this purpose, as new pots soak all the moisture from the soil. Morse's prepared bulb fibre or a light rich soil is the proper potting material. Use a four or five-inch pot. A little sharp sand sifted under the base of each bulb at the time of placing it in position will be beneficial. Then add more fibre until the crown or top of the bulb appears just above the surface. After potting, give a good watering and put them in a cool, dark place for eight or ten weeks, at which time the bulbs will be well rooted. Water thoroughly the first three days and then once a week only until the pots are brought into the light. This should be done gradually, bringing them to a north or shaded window first and into the sunlight when just ready to flower. Keep the pots moist but never wet.

In order to get fine, long stems, bring the bulbs which you are forcing out from the cold, dark rooting place into a warm, dark place, instead of into the light. A covering of moss gives this result and is easy to handle. Add more moss as the flowering stem grows. This will take about three weeks and the bulbs are then ready to be brought into the light.

\section{Morse's Prepared Bulb Fibre}

Early flowering bulbs can be grown in Morse Prepared Fibre right in the house and flower better than if growing in ordinary soil. The fibre will retain moisture longer and more evenly, and supply all plant food. No drainage is required for growing in this way; the fibre should be moist but not saturated, and if too much water should have been given, tip the bowl and empty same. Bowls are used for holding the fibre and growing the flowers. They always keep sweet on account of charcoal in the fibre. Hyacinths do well, also early Tulips, Freesias, Narcissus, Crocus, Jonquils, Snowflakes, Allium, Spanish Iris, etc., flower freely. Fibre comes moist. (Postage additional.) Lb., 15c; 5 lbs., $60 \mathrm{c} ; 25$ lbs., $\$ 2.50 ; 100$ lbs., $\$ 8.00$.

PARCELS POST. A new and adequate Parcels Post law now applies to shipments of Seeds, Bulbs, Tools, Plants and Garden Supplies (except poisons and liquids) to all of the United States; also to Alaska, Canal Zone, Guam, Hawaii, Porto

DOMESTIC PARCEL POST RATES
On Seeds, Plants, Bulbs, Roots, Books, Tools, Etc.,
within the U. S. and Possessions.
Rico, and the Philippines. Packages are subject to a limit of Maximum Weight in the 1st and 2nd zones of $70 \mathrm{lbs}$.; and in all other zones, 3rd to 8 th, of 50 lbs. The Maximum Size of a package is 84 inches for combined length and largest girth. Insurance will be effected oniy when asked for and remitted for as follows: Parcels to the value of $\$ 25$ or under for $5 \mathrm{c}$; to the value of $\$ 25$ to $\$ 50$ for $10 \mathrm{c}$.

FOR PARCELS WEIGHING 8 OUNCES OR LESS containing seeds, bulbs, plants, or books only the rate of postage to all zones is $1 \mathrm{c}$ for two ounces or fraction. (Over 8 oz. the above zone rates apply.)

FOR PARCELS CONTAINING FOURTH CLASS MATTER-other than the aboveup to four ounces is permitted to all zones at 1e per ounce. (Over $4 \mathrm{oz}$. the above zone rates apply.)

ZONE RATES may be had by application to your postmaster, who will tell you the zone which you are in with reference to San Francisco, or we will tell you as nearly as we ean if you write us.

OUR PRICES plainly state whether postage is included, and if not what the weight of the bulbs is estimated to be. On our order sheet for bulbs is a column especially for weights, and these should be set down and added, and figured at zone rates as above table at the end of the sheet for the total shipment. This will make the figuring very simple. Should there be a slight difference between estimated weight and actual weight we will put in extra bulbs or seed. 


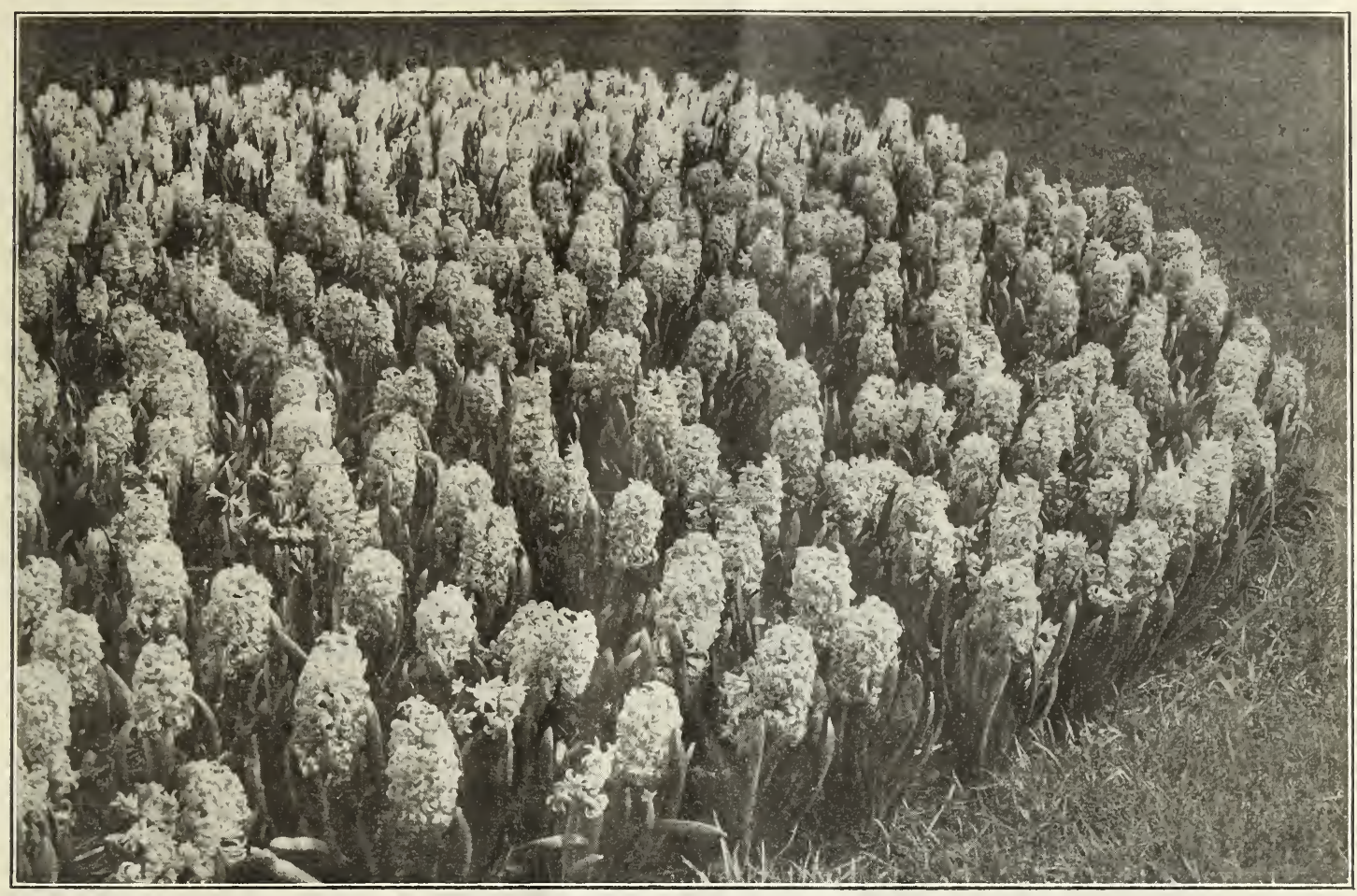

Morse's Single Hyacinths

For prices and varieties see Page 2

Intermediate Size Named Varieties

\section{Morse's Hyacinths}

Hyacinths are very easy to grow, and can be grown in many different ways, out of doors, in pots, or fancy jardinieres with Bulb Fibre, or in Hyacinth Glasses with water. For outdoor growing care should be taken that ground is well forked over with a good supply of Manure. Set the Bulbs from four to five inches deep and seven or eight inches apart. Most planters make a mistake of planting nearly all Bulbs too shallow, causing the top growth to sprout too quickly which produces short stemmed Flowers. By planting Bulbs, especially in loose soil or sand, give them extra depth to produce roots so that they will take food value from the soil.

For pot growing. use sandy loam and bury the pots in the Garden for five or six weeks or keep in a dark place to produce roots; then bring them into the louse to force into blooming. To grow in jardinieres, without drainage, use Morse's Bulb Fibre as listed on inside of front cover. Many other varieties of Bulbous stock can be successfully grown in Bulb Fibre and this is a very nice way to grow them for house decoration there being no drainage required jardinieres can be placed on different furniture without fear of marring same. Special Hyacinth Glasses can be purchased from us at prices listed on back cover, which also makes a very clean and ornamental display.

Our named Hyacinths are of first size, large, healthy Bulbs, and will produce the finest flowers. Such varieties as La Grandesse, King of the Belgiums, Dr. Lieber, King of the Blues, Albertine, La Innocence, Gigantea, Herman, King of the Yellows, etc., are especially hardy and easy to raise.

Our "Prepared Hyacinths," which are listed below, are special stock for Early Flowering, and enables the Grower to have blooms at Christmas or early in January. They are splendid for planting in pots and pans. These Hyacinths should, however, be stored away in a cool. dark place a little longer than other varieties and will give splendid results. We expect our "Prepared Hyacinths" to arrive here about the 1st of September, so place your orders early.

\section{"Prepared Hyacinths"}

By mail, postage additional. Weight, 2 lbs. per dozen.

\begin{tabular}{|c|c|c|c|c|c|}
\hline FIRST SIZE & Each & Doz. & SECOND SIZE & Each & Doz. \\
\hline Dr. Lieber, Sky Blue. & $\$ .25$ & $\$ 2.50$ & Dr. Lieber, Sky Blue $\ldots \ldots \ldots \ldots \ldots \ldots$ & $\$ .17$ & $\$ 1.75$ \\
\hline Gertrude, Rose Pink.. & .25 & 2.50 & Gertrude, Rose Pink... & .17 & 1.75 \\
\hline Lady Derby, Light Pink & .25 & 2.50 & Lady Derby, Light Pink & .17 & 1.75 \\
\hline L'Innocence, Pure White & .25 & 2.50 & L'Innocence, Pure White. & .17 & 1.75 \\
\hline
\end{tabular}

\section{Hyacinths}

(SINGLE NAMED VARIETIES)

These are first size bulbs suitable for growing in Glasses, Fibre, pots and gardens. Collection of saparate varieties our selection at $\$ 2.00$ per dozen, $\$ 15.00$ per 100 . Postage extra, at rate 3 lbs. per dozen; 15 lbs. per 100 .

\begin{tabular}{|c|c|c|c|c|c|c|c|}
\hline & Each & Doz. & 100 & (Red, Rose and Pink) & Each & Doz. & 100 \\
\hline Lieber, Lavender Blue... & $\$ .20$ & $\$ 2.00$ & $\$ 15.00$ & Gertrude, Rosy Pink... & & $\$ 2.00$ & $\$ 15.00$ \\
\hline and Maitre, Deep Porcelain Blue & .20 & 2.00 & 15.00 & Gigantea, True Pink... & .20 & 2.00 & 15.00 \\
\hline , Dark Blue.... & .20 & 2.00 & 15.00 & Jacques, Bright Pink. & .20 & 2.00 & 15.00 \\
\hline , Pur & . 0 & 2.00 & 15.00 & Kohinoor, Fine Rosy & & $\$ .00$ & 15.00 \\
\hline ure Blue....... & .20 & 2.00 & 15.00 & Moreno, Deep Pink......... & .20 & 2.00 & 15.00 \\
\hline $\begin{array}{l}\text { Wm. Mansfield, } \\
\text { Single Whites }\end{array}$ & .20 & 2.00 & 15.00 & $\begin{array}{l}\text { Queen of the Pinks, Rosy Pink....... } \\
\text { Single Yellows }\end{array}$ & .20 & 2.00 & 15.00 \\
\hline e, Compact $\mathrm{Y}$ & .20 & 2.00 & & City of Haar'em, Pure Yellow, . . .... & .20 & 2.00 & 15.00 \\
\hline Pure & .20 & 2.00 & 15. & & .20 & 2.00 & 15.00 \\
\hline low V & 20 & 2.00 & 15.00 & King of the Yellows, Golden Yellow. & .20 & 2.00 & 15.00 \\
\hline
\end{tabular}

Index to this Catalog See Inside of Back Cover 


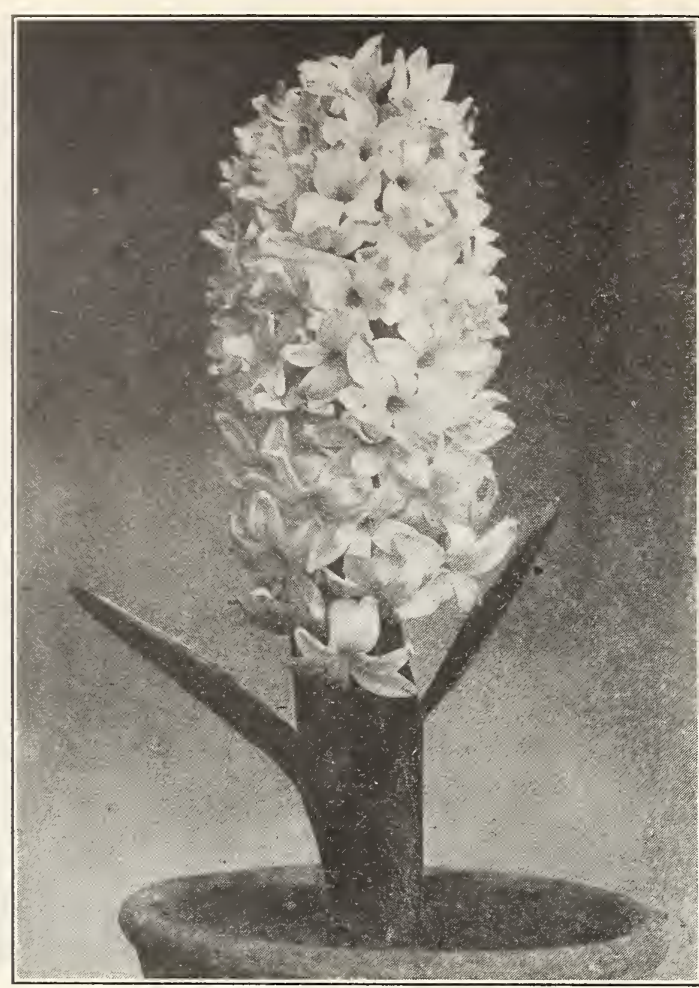

Hyacinth growing in pot with soil, or jardiniere with

\section{Double Hyacinths}

Weight, 3 lbs. per dozen

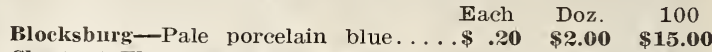

Chestnut Flower-Rose; large flower. . .20

Garrick-Bright blue .............20 $2.00 \quad \mathbf{2 0} \mathbf{2 0 0}$

Gen. Kohler-Deep blue. . . . . . . . . . 20 2.00 15.00

Isabella-Blush white $\ldots \ldots \ldots \ldots \ldots \ldots . .20 \quad \mathbf{2 0}$.01 15.00

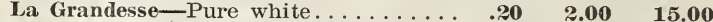

Noble Par Nerite-Deep rose....... .20 $2.00 \quad \mathbf{2 0} \quad \mathbf{1 5 . 0 0}$

President Roosevelt-Rose pink...... $.20 \quad \mathbf{2 0 0} \quad \mathbf{1 5 . 0 0}$

\section{Intermediate Hyacinths}

Excellent size for growing in pots or out of doors, where named varieties are required.

Postage additional; weight, 21/2 lbs. per dozen; 14 lbs. 100

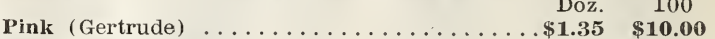

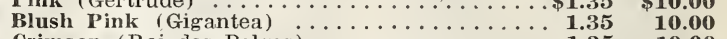

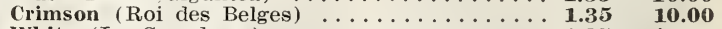

White (La Grandesse) $\ldots \ldots \ldots \ldots \ldots \ldots \ldots \ldots \ldots$

White (L'Innocence) .................. 1.35 $\mathbf{1 0 . 0 0}$

Yellow (City of Haarlem) $\ldots \ldots . . .1 .35$

Dark Blue (King of the Blues) ........................

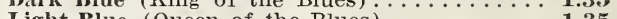

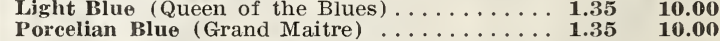

\section{Single Bedding Hyacinths}

In different shades, and are excellent for massing, bedding and borders.

When required by mail add postage at the rate of $2 \mathrm{lbs}$. per dozen; 12 lbs. per 100.

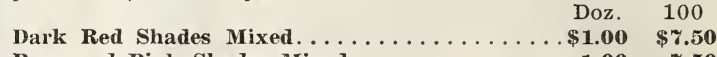

Rose and Pink Shades Mixed.............. 1.00 \%.50

Dark Blue Shades Mixed.............. 1.00

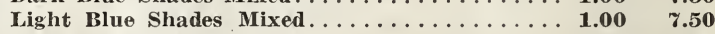

White and Blush White Shades Mixed,....... $1.00 \%$

Yellow Shades Mixed................ 1.00

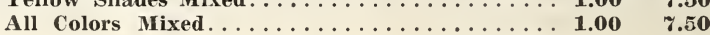

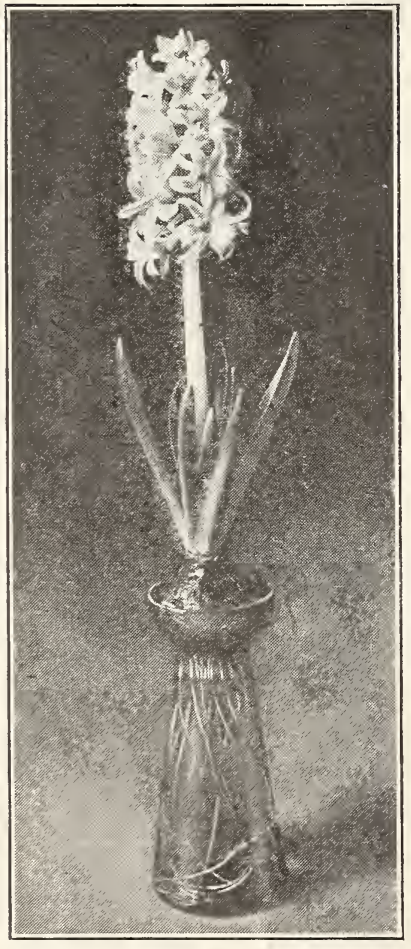

Hyacinth growing in special $\mathrm{Hy}$ acinth Glass. We have fine stock of imported and Domestic Glasses. See inside of back cover.

\section{Early Flowering Gladiolus}

Without doubt, we think Early Flowering GLADIOLUS are one of the most satisfactory Flowers grown. Easy to grow and give an abundance of blooms with the least care of any Flower we know of. Our stock of these will be ready for delivery September to January. Prices are postpaid. These Baby Gladiolus will keep two weeks in water after cutting. See cut on back cover.

Doz. 100

Blushing Bride (White with beautiful pink Carmine flakes) . . . . . . . . . .75 5.00

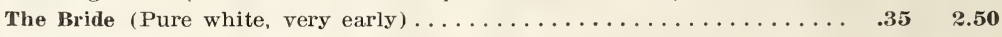

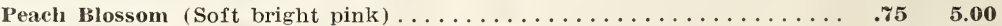

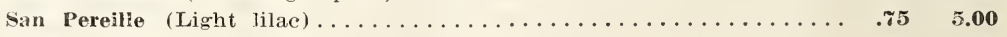

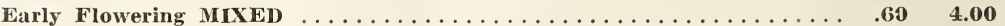

\section{Gladioli Primulinus Hybrids}

This is our first introduction of this beautiful type of Gladioli. Their colors vary from pale yellow to light salmon. Petals are quite thin and are somewhat different in form than ordinary Gladioli. Very dainty and slender and highly recommended for cut flowers. Each bulb produces severa] spikes of flowers.

Aurora-Copper color, very attractive, early . . . . . . . . . . . .20 1.75

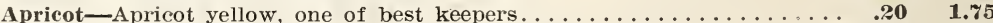

Conspicuus-Yellow with red blotch, very showy ..............20 1.75

Leander-Heliotrope blue; very early, distinct. . . . . . . . . . . . . . . . .40 3.50

L'Unique-Bronze with orange yellow center............... .20 1.75

Queen Victoria_-Bright pink, silver rose throat. . . . . . . . . . . . . . .20 1.75

Violet Queen-Light violet shade, early . . . . . . . . . . . . . . .20 1.75

Yellow Primulinus-Rich golden yeliow . . . . . . . . . . . . . . . . 15 1.25

Primulinus Mixed-A mixture of the above 9 varieties, 1 Bulb of each. $\$ \$ 1.30$ If required by mail, add postage at the rate of $1 \frac{1}{2} \mathrm{lbs}$. per dozen.

Our Late Flowering Gladioli are listed on page 9 . It is advisable to order these early to prevent disappointment, in being too late for our new varieties. 


\section{Morse's Imported TULIPS}

Tulips are a very satisfactory flower, both for garden and pot culture. They require very little attention, and will grow in any fairly good soil.

Prepare your soil by applying a coating of bone meal and deep forking. Plant bulbs four or five inches deep, eight to nine inches apart. These planting directions apply to all the different types.

Our list of different varieties are grown for us by one of the best growers in Holland. and we do not hesitate to say that our stock is of the very best.

\section{Darwin Tulips}

This is the favorite type of I'ulips. They excel in brilliancy of colors, perfect form of flowers. with long, stout stems. For a beautiful effect in borders, and planted in small groups among shrubs, they are unsurpassed. As a cut flower, they are of great value, good keepers and come in the very lovely shades of mauve, violet, maroon, pink and red. Our complete list below of well balanced varieties will help our customers to choose a collection of these bulbs, which we know will give the best results.

In ordering by mail, add additional nostage at the rate of $3 / 4 \mathrm{lb}$. per dozen, $4 \frac{1 / 2}{\mathrm{lbs} \text {, per }}$ 100

Six at dozen rate; 50 at 100 rate.

Doz. 100

salmon shaded blush...... $\$$. . $\$ 4.75$

Blue Celeste (New) - Violet

blue. Very fine and distinct.

30e each .............. 3.00

Carl Becker - Rose carmine

shaded, large flowers, stout

stems $\ldots \ldots$ lara But- Exquisite $\ldots \ldots \ldots$ soft salmon pink

City of Haarlem (New) - im:
mense vermillion scarlet, blue

mense vermillion scarlet, blue
base. 30c each........... $\mathbf{3 . 0 0}$

$65 \quad 4.50$

Donders_-Darkest blood red with

Edme-Deep cherry rose, silver pink edges... $\quad .75$

Erguste-Pure lilac, inside violet white base .80

Europe-Pure cherry red with white center... .75

Feu Brilliant-Brilliant clear scarlet, very large.

Fra Angelico-Black maroon; finest of this color .75

Flamingo-Pure shell pink, pointed flower....

Gen. de Cordous - Scarlet, fine for cutting.....

Glow-Brilliant vermillion, blue and white

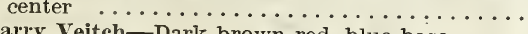

Harry Veitch-Dark brown red, blue base......

Isis-Scarlet, blue base; margin white.......

King Harold-Deep blood red, very large......

La Tristesse-Mauve and white shaded. .

La Tulipe Noire-Finest black, very large flower

Marconi-Large purple violet with yellow center

Margaret-Lovely blush pink, globular form.

Mauve Claire-Mauve violet silvery edge; dark

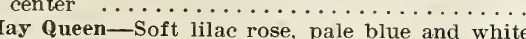

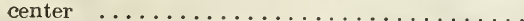

Mrs. Farncombe Sanders-Scarlet with clear

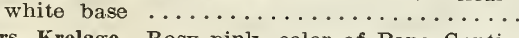

Mrs. Krelage-Rosy pink, color of Papa Gontier

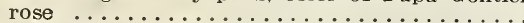

Pride of Haarlem-Giant flowers of deep rose shade $\ldots \ldots \ldots \ldots \ldots \ldots \ldots \ldots \ldots \ldots \ldots \ldots \ldots \ldots \ldots \ldots \ldots \ldots$

Prof. Rauwenhof-Cherry rose, flower enormous

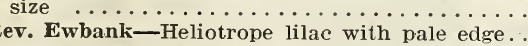

Rev. Ewbank-Heliotrope lilac with pale edge..
Sieraad Van Flora-Crushed strawberry, large

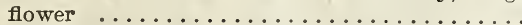

Painted Lady-Creamy white, tinged with helio-

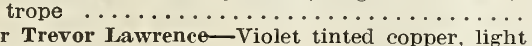

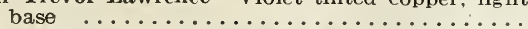

Suzon-Flesh pink, deeper inside, blue base....
Van Poortvliet-Light cherry red, very attractive $\ldots . . . \ldots \ldots$

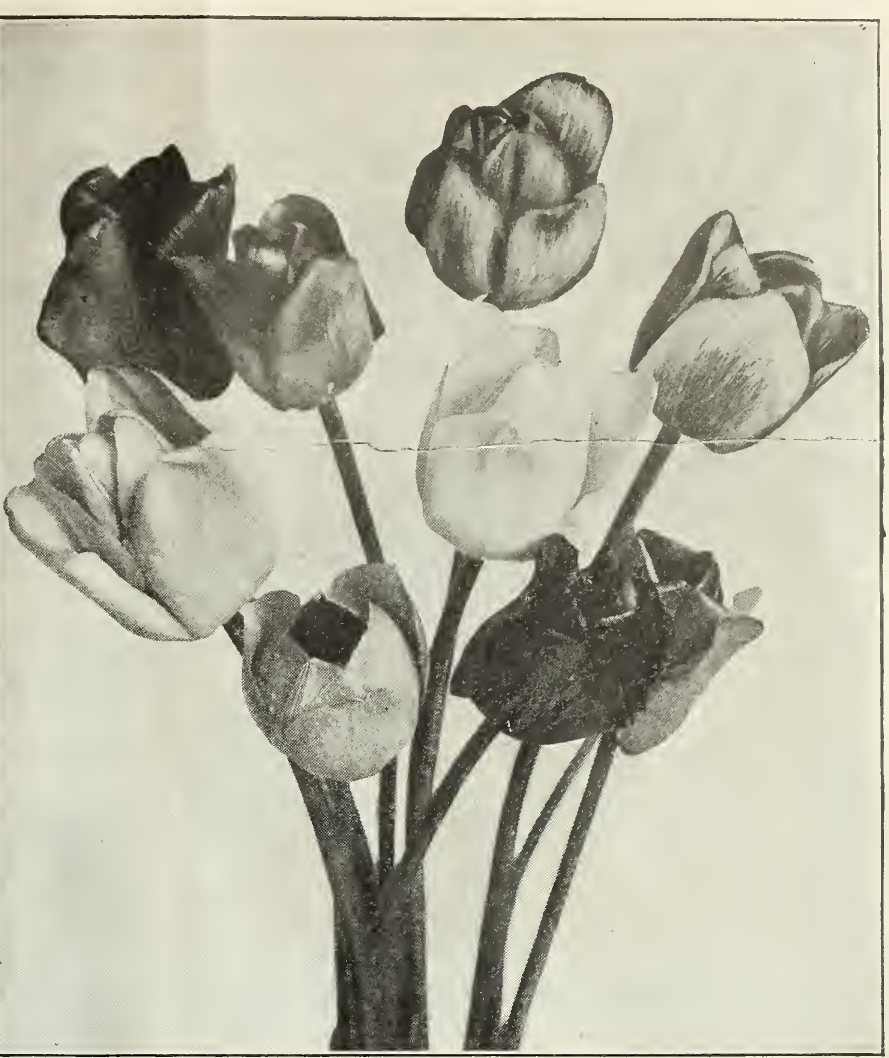

Darwin Tulips

5.75

5.25

5.25

5.75

5.75

5.75

5.50

4.75

$.85 \quad 5.75$

5.75
100
$\$ 5.25$
5.25
5.75
5.50
5.25
5.50
5.00
5.75
4.75
Wedding Veil-Silvery gray light lavender....\$ .70 $\$ 4.75$ White Queen-White tinged blush...........75 5.25 William Pitt-Very dark scarlet with purple
shade on outer petals...............1.00 6.75
Whistler-Crimson scarlet, blue base, white edge,
extra fine .................. $85 \quad 6.00$ Wally Moes-Soft silvery heliotrope........ .85 Morse's Mixture Named Darwins............ .75 $\mathbf{5 . 0 0}$
$\$ 4 \% .50$ per 1000

Collection of sixty Bulbs, two of a kind, our

selection. Collection ............\$4.50 prepaid

Darwin Mixture, as from the fields......... .60 4.00

\section{Morse's Breeder Tulips}

Old Dutch Type Tulips, in purples, bronze, grey and lilac yellow and bronze, brown and orange. Flowers are mostly large, perfect form and borne on tall, stout stems. We offer these only in mixtures of the very best quality and stock, with the exception of Bronze Queen, which during the last few years has created a tremendous demand, the color being so different from any other Tulip.

Bronze Queen-Tan, apricot shades.......\$1.00 $\$ 6.75$

Breeders Mixed ................... .75 5.00

Postage extra

\section{Morse's Special Mixture of all Long- Stemmed Tulips}

This mixture enables our customers to order good assortments of Tulips without the trouble of going through the entire list. They are made up by ourselves from named varieties, and have all the classes, sorts, and colors that go well together. We take particular care in making up this mixture and where all colors mixed are required, these will be most satisfactory.

Price per dozen, 70c; 100, \$4.75; 1000, \$45.00.

Postage extra.

Six at dozen rate, 50 at 100 rate, and 500 at 1000 rate 


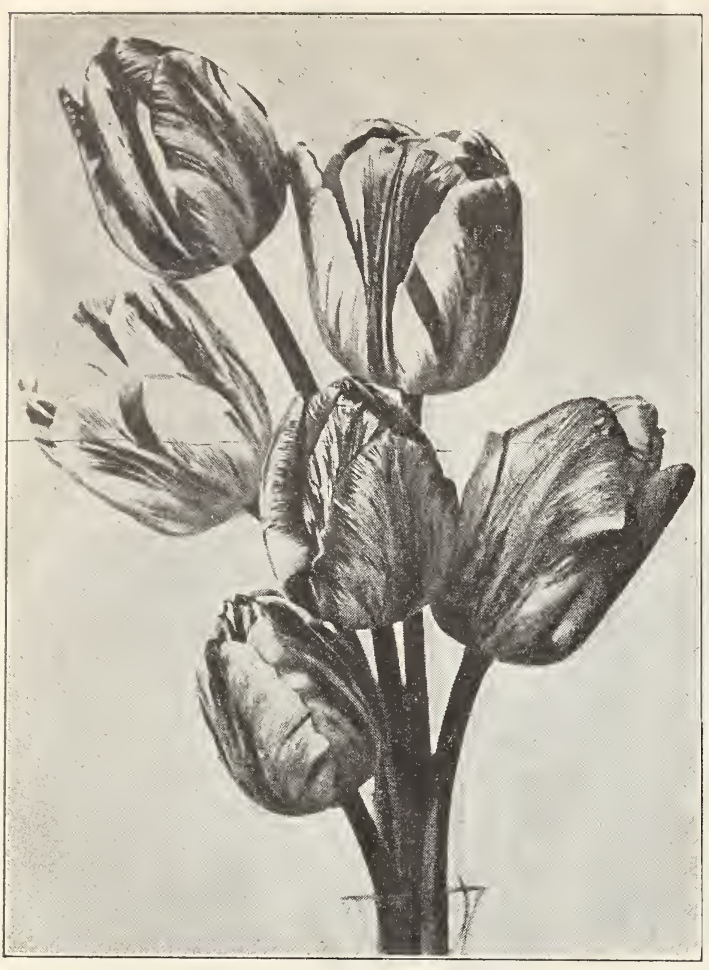

Morse's Giant Striped Tulip

\section{Morse's Late or May Flowering Tulips}

This type of Tulip is much prized by all, and can be grown in conjunction with the Darwin and Breeder Tulips. The best Yellows, Pinks, and Reds, are found in this type. They have good long stems, and produce a wonderful effect when planted in beds or borders. Partial shade will produce the best blooms, and varieties, such as Gesneriana Major, Gesneriana Lutea, Inglescomb Pink, are among those most extensively grown. Our list below includes the very best selections with full description of color.

Postage rates same as for Darwins. Write for special prices in large quantities.

Gesneriana Major-Most brilliant and dazzling

crimson with black center and pointed petals.\$ $.75 \quad \$ 5.25$ Gesneriana Lutea-Beautiful golden yellow; very

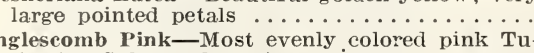
Inglescomb Pink-Most evenly . colored pink TuInglescomb Scarlet-Bright flame red; distinctive and handsome ........................... Isabella (or Blushing Bride) - Creamy white and
pink, dark rose center...............

La Merveille-Salmon rose overlaid with orange-

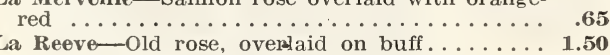

Picotee (Maiden's Blush) — White margined carmine rose

Parisian Yellow-Lovely clear yellow, pointed petals .............................. yellow

White Swan-Best pure white Tulip.

\section{Morse's Giant Striped Tulips}

This splendid stock is really the finest procurable and any lover of showy, brilliant colors will find delight in these wonderfully striped varieties. 65e doz.; \$4.50 100. Postage extra.

\section{Morse's Early Tulips}

Double and Single varieties.

Excellent for growing indoors in pots, and especially in fancy jardinieres with Morse's Bulb Fibre, as listed on inside of front cover.

Stems are short and come into bloom very early. The brilliant colors of these early varieties make them the best for house or conservatory decoration.

Also good for borders and massing in beds.

$$
\text { (Postage extra.) }
$$

Artus-Single bright red, very fine flower.....\$ $.60 \quad \begin{array}{lll}\text { Doz. } & 100\end{array}$

Coronne D'Or - Double, deep yellow shaded

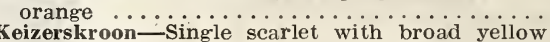
margin $\ldots \ldots \ldots \ldots \ldots \ldots \ldots \ldots \ldots \ldots . .65 \quad 4.50$

Mon Tresor - Single, fine pure yellow; extra early

Murillo-Double, delicate flesh pink; best forcing variety

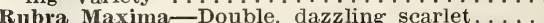

Vermillion Brilliant-Single, vermillion scarlet.

White Hawk-Single, true pure white, egg

White Haped flower $\ldots \ldots \ldots \ldots \ldots \ldots \ldots \ldots \ldots \ldots \ldots$
sha.

\section{Morse's Parrot Tulips}

This class of Tulip is a distinct type. Each flower, having a combination of colors all beautifully and quaintly striped, resemble the beak of a parrot. As easily grown as other types, and particularly artistic as cut flowers.

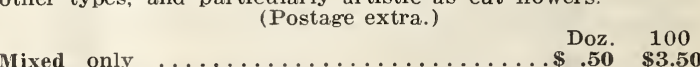

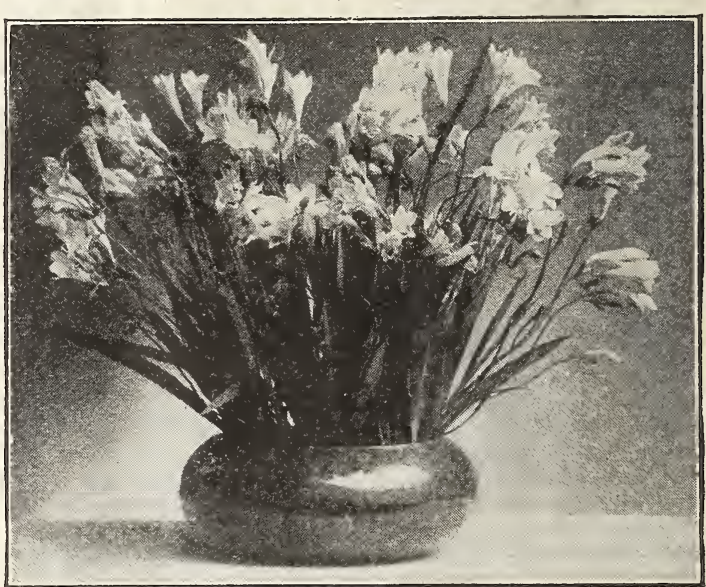

\section{Morse's Freesias}

of all the beautiful sweet flowers, none surpass the Freesia, and this year we have all those beautiful shades of Pale Pinks, Reds, Lavenders, Yellows, etc. They are good for borders, pots, hanging baskets, and window boxes. Ready any time after August 1st, and all prices are postpaid.

Purity-Our improved strain of this Doz. $100 \quad 1000$ well known variety. MAMMOTH BULBS

Purity-Medium size Bubs . . . . . . .

Purity-Small size for bedding .....

Morse's Tall Pink (New) - Taller than

the other varieties. Soft shell pink.

Morse's Pink and Red (New)-This is really a deep pink shade. Very pretty

Morse's Splendens-The brightest color in Freesias we know of. Almost

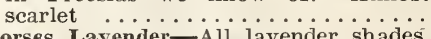

Morses Lavender-All lavender shades.

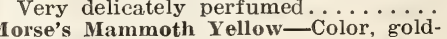

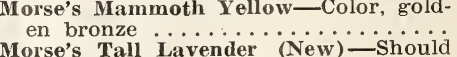

Morse's Tall Lavender (New) -Should be grown with Morse's Tall Pink... Morse's Rainbow Mixed-Mixture of all
the varieties listed above......... Tritona-This is a beautiful orange flower very much jike Freesia and should be grown with them.......

$\begin{array}{rrr}.50 & \$ 3.50 & \ldots \\ .30 & 2.00 & \$ 15.00 \\ .20 & \mathbf{1 . 0 0} & \mathbf{8 . 0 0} \\ .75 & 5.00 & \ldots \\ .75 & 5.00 & \ldots \\ .75 & 5.00 & \ldots \ldots \\ .75 & 5.00 & \ldots \ldots \\ .75 & 5.00 & \ldots \ldots \\ .75 & 5.00 & \ldots \ldots \\ .75 & 5.00 & \ldots \ldots \\ .50 & 3.75 & \ldots \ldots\end{array}$




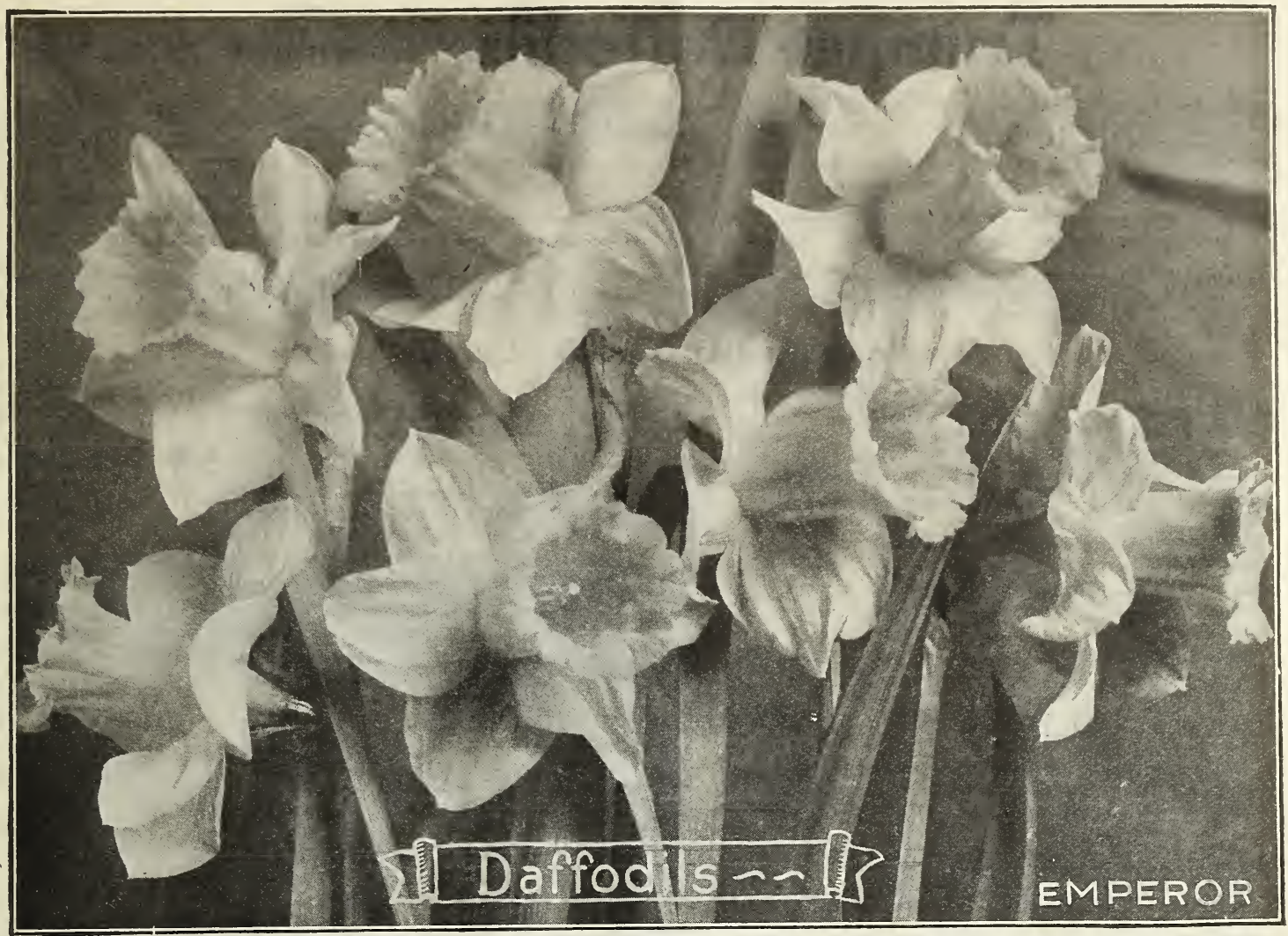

\section{Daffodils}

Daffodils are probably the most popular of spring flowering bulbs. Blooming so early, their wonderful display of yellow beauty is the advance agent of spring. From February well until May, Daffodils will bloom if selection of varieties is carefully made. We have classified the following varieties, which will make selection easy. Trumpet Daffodils, Crown Daffodils, Double Daffodils, Poeticus Narcissus, Poetaz and Polyanthus Narcissus, and Jonquils. Many new varieties are included.

Culture: Daffodils and Narcissi appear to greater advantage if planted in partial shade. This will prolong their bloom and will help to retain the color of the red and orange cup varieties. Set bulbs from four to five inches deep and eight inches apart. It is a good plan with all bulbs planted out of doors to cover ground on top with four or five inches of light material, such as straw or leaves, removing same after six or seven weeks. This will give good root, the results will be extra large flowers. Do not cut the leaves after blooming, but let them die back; if cut back, severely, you will have no flowers the following season.

Daffodils and Narcissi can also be grown successfully in pots. Three or four in a pot, according to size, but will require quite a lot of water unless the pots are sunk in soil for six or eight weeks, which is a very good plan.

\section{Daffodils, Large Trumpet}

Postage additional. $11 / 2$ lbs, per dozen, 12 lbs. per hundred, except for Emperors, which are 3 lbs. per dozen, 22 lbs. per hundred.

Emperor-One of the most well known late Daffodils. Perianth is broad and overlapping. Trumpet very large. Entire flower is pure yellow. Stems long: fine for cutting. Should be grown in every garden. Large Bulb

Bi-Color Empress - Perianth is pure white and trumpet golden yellow. A magnificent flower, and truly a good $\mathrm{m}$ a $\mathrm{t}$ e for Emperor. Such a well known variety needs no further description $\ldots \ldots \ldots \ldots \ldots \ldots \ldots$

Bi-Color Victoria-This variety is some what later than Empress, but earlier than Bi-Color Grandee, and we highly

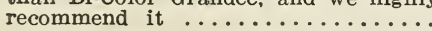

Ea. Doz. 100

$.10 \$ 1.00 \$ \% .00$

\author{
10 $\$ 1.00$
}

$\begin{array}{lll}.10 & 1.00 & 7.00\end{array}$

$.09 \quad .90 \quad 6.00$ Bi-Color Grandee-This is a very large
flowered variety with white petals and yellow trumpet, but is somewhat different in appearance, as the perianth overlap. Rather dwarf. Very late flowering $\ldots \ldots \ldots \ldots \ldots \ldots \ldots \ldots \ldots \ldots \ldots \ldots \$ .09 \quad \$ .90 \quad \$ 6.00$ Golden Spur-Perianth, yellow. Trumpet, golden yellow. One of the late varieties, but excellent for cutting and very fragrant. Largely grown by market gardeners. ................ King Alfred-This is a perfect flower. Very large; trumpet long, and deep yellow. And a floriferous producer. No doubt the best of the all-yellow
varieties. Mammoth Bulbs........ 


\section{Trumpet Daffodils - Continued}

Mme. De Graaf-Perianth, pure white. Trumpet, soft primrose. Exquisitely rolled back at brim. Large, well formed flowers. Suitable for outdoor and pot culture. Per each, 15c; dozen, \$1.50; $100, \$ 10.00$.

Olympia-The largest of all Daffodils. Hugh straight trumpet of slightly deeper color than perianth, which is a clear primrose yellow. Per each, 30c; dozen, \$3.00.

Princeps Maximus-This is one of the popular early varieties. Perianth, sulphur yellow, with drooping trumpet. Good for massing, borders, and pot growing, and one of the easiest grown. Per each, 8c; dozen, 80c; 100, \$5.50.

Trumpet Major-One of the most popular clear yellow varieties. Both perianth and trumpet of the same color. A medium size flower, valuable for bedding, cutting, and forcing. Per each, 8c; dozen, 80c; $100, \$$ J.50.

\section{Crown Daffodils (Challice Cup or Star)}

Barrii Conspicuus-Well known variety Ea. Doz. 100 with broad yellow periainth. With short, broad crown. Edged with orange scarlet. Large flower.....\$ $.09 \quad \$ \quad .90 \quad \$ 6.25$

Firebrand (New) - Perianth, creamy white, shaded soft yellow at base. Cup, intense firey red. Prettily fluted. Exceptionally good ............

Gloria Mundi-Perianth, primrose yellow. Broad petals, crown, dark chrome at base, deepening to orange

\section{$.15 \quad 1.25 \quad \ldots \ldots$}

$\begin{array}{lll}.09 & .90 & 6.00\end{array}$

Lady Godiva-Perianth white, beautiful form. Cup medium size; yellow,

Ea. Doz. 100 edged orange scarlet...........\$ .09 $\$ .90 \quad \$ 6.00$

Red Beacon (New) - Broad perianth, ivory white, with pale sulphur tone at base. Fluted and frilled cup of most vivid orange scarlet. Wonderfully striking flower $\ldots \ldots \ldots \ldots \ldots \ldots \ldots$

Sir Watkin-Sulphur yellow, perianth. Cup, deep golden yellow, and almost as large as those of the trumpet class

\section{Double Daffodils}

Double Daffodils are long blooming types. They resemble Carnations and Gardenias, in form of flower, with the exception of Von Sion, which is a double trumpet variety.

Alba Plena odorata - (Double White
Poet's Narcissus) - Pure white and
fragrant. Late blooming.......\$ .07

Orange Phoenix-(Eggs and Bacon)Very large variety. White and orange. Fine for pot culture, and a very double flower ...............\$ $.09 \quad \$ \quad .90 \quad \$ 6.50$

Sulphur Phoenix-Large creamy white flower with sulphur yellow center. One of the best double sorts. Very

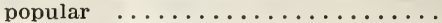

Von Sion - Double trumpet variety. Greatly prized, and is excellent for bedding, forcing and cut flowers. A pure yellow $\ldots \ldots \ldots \ldots \ldots \ldots \ldots \ldots \ldots \ldots, \quad 09 \quad .90 \quad 6.00$

\section{Jonquils (Narcissi Jonquila)}

These sweet flowers come in several classes. The single varieties are sweet scented, and are borne in clusters. Other varieties are like miniature Daffodils in both the single and doubles. They are very. easily grown and are splendid for cut flowers. They are simply lovely.

If wanted by mail, add $3 / 4 \mathrm{lb}$. to the dozen, and $5 \mathrm{lbs}$. per 100 on Campernelle and Rugulosus. Others postpaid.

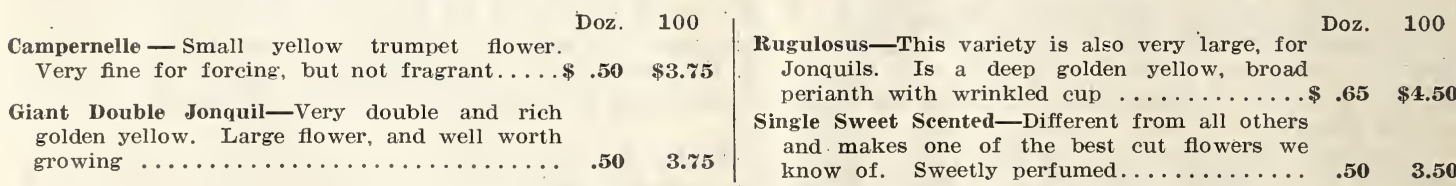

\section{Poeticus Narcissus}

We are introducing some new varieties of Poeticus Narcissi this season. Poeticus Pheasant Eye and Ornatus are well known varieties and need very little description. The other five are entirely new and the first time they have been offered here, and a great improvement on the older ones. Flowers are much larger and of more substance. The pure white perianth and colored cups of these varieties make them very attractive and will be appreciated by all those who plant them.

\begin{tabular}{|c|c|c|c|}
\hline -Beautiful white & & $\begin{array}{c}\text { Doz. } \\
\$ 2.00\end{array}$ & $\begin{array}{l}100 \\
\ldots \ldots\end{array}$ \\
\hline of Lisse (New)-This is a great improvement over Ornatus. $\mathrm{N}$ & .10 & 1.00 & $\$ 7.00$ \\
\hline r (New)-Pure white perianth, rich deep red eye. Extraordin & .20 & 2.00 & \\
\hline ed eye. Very a & .30 & 3.25 & \\
\hline & .10 & 1.00 & 7.50 \\
\hline ose, very large Bulbs. & .07 & .75 & $\mathbf{5 . 0 0}$ \\
\hline rnatus-Well known early flowering sort. Perianth, white; red cup. Ordinary bulbs .......... & .05 & .50 & 3.50 \\
\hline heasant's Eyo-Late variety. White perianth, cup resembling a pheasant's eye................. & .06 & .60 & 4.25 \\
\hline
\end{tabular}




\section{Polyanthus Narcissus}

A very fragrant, sweet scented type, and very early. Can be grown outdoors or in pots or water with gravel. Each stem bears from ten to twenty blossoms. If by mail add $1 \frac{1}{4} \mathrm{lbs}$. per dozen and $10 \mathrm{lbs}$. per 100, except the Chinese Sacred Lilies, which weigh 3 lbs. per dozen. Paper White Grandiflora-Snowy white
blossoms with large petals. Very free

oldest types .....................................

Grand Monarch-Broad white perianth with primrould be more widely grown...

$\begin{array}{ccc}\text { Ea. } & \text { Doz. } & 100 \\ .07 & \$ .70 & \$ 4.75\end{array}$

$10 \quad 1.00 \quad \% .00$
Grand Soleil I'Or-A rich clear yellow with orange cup. Commonly called (Yellow Paper White) ............

Chinese Sacred Lily-A variety usually grown in Lily Bowls with water. These are selected Bulbs imported from China. Large Bulbs....... $20 \quad \mathbf{2 0 0} \quad \mathbf{1 4 . 0 0}$

\section{Poetaz Narcissus (Hybrids)}

These are different from the Polyanthus type. 'The individual flowers of this class have more or less the Poeticus size, but the perfume is very delicate.

Elvira-Borne on long graceful stems, heads three or four large flowers with broad white petals and a Ea. Doz. 100 golden yellow cup edged orange. Very delicate fragrance. Good for forcing ..............

Klondyke (New) - Both perianth and cup a beautiful deep golden yellow. Six or seven flowers on the

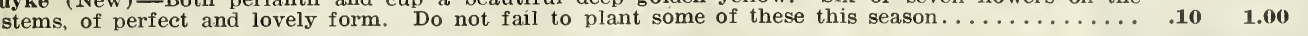

$\mathbf{9 0 0}$

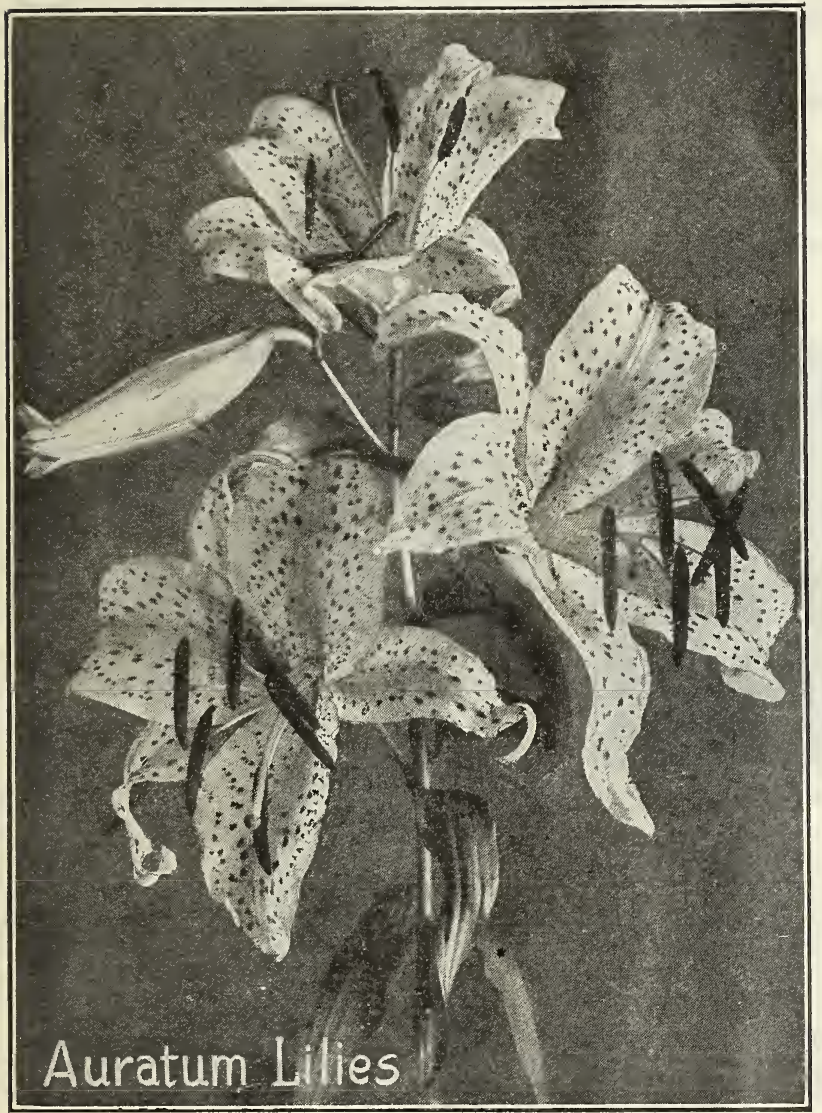

\section{Lilies}

Our Lilies are all imported stock and the very best we can purchase. To grow Lilies successfully they should be planted in a well shaded and drained location. any time from November to February. Place the Bulbs about five inches deep and twenty inches apart in good soil where some Leaf Mould and Fertilizer has been mixed in. They come in a great variety, which the description of each below will show. No flower is more lovely than the Japanese Lily. If required by maill, add 3 lbs. per dozen with the exception of Auratum and Speciosm, large size, for which add five lbs, per dozen. Elegans, Krameri, Leopard, Rubellum. White and Yellow Callas, 11/2 lbs. per dozen.

Auratum (Gold Banded Lily) - The most popular of hardy garden Lilies. Blossoms have six large petals, white studded with spots. A golden band running through the center of each petal. Price 25c each, \$2.50 per doz, \$17.00 per 100. Extra large Bulbs, 45e each, \$4.50 per doz, \$32.50 per 100 .

Auratum Platyphyllum-Similar to Auratum, only larger. Petals studded with crimson and chocolate spots. Price 35e each, \$3.50 per doz., \$25.00 per 100.

Elegans Orange-One of the most beautiful Lilies in cultivation. Price $\mathbf{2 0 c}$ each, \$2.00 per doz.

Elegans Antrosanguinea-A dark blood red Lily of elegant appearance. Price 35c each, \$3.50 per doz.

Elegans Incomparable - Deep crimson, slightly spotted black. Flowers very large and one of the most beautiful. Price 20e each, \$2.00 per doz.

Candidum-Hardy St. Joseph or Annunciation Lily for early delivery only. Price 20c each, \$2.00 per doz.

Krameri-A distinct Lily from all others. Very large pink flower. Price $\mathbf{2 0 c}$ each, $\$ \mathbf{2 . 0 0}$ per doz.

Harrisi-The Bermuda Easter Lily. Pure white trumpet shape. Early flowering, grown by florists for the Easter trade. Price 30c each, \$3.00 per doz.

Longiflorum Giganteum - Japanese Easter Lily. Splendid for pot growing and outdoor planting. One of the best. Price 25e each, \$2.50 per doz.

Ea. Doz. 100

Speciosum Album-Flowers pure white. Petals recurved. Very hardy. Beautiful type. Price....\$ .25 \$2.50 \$17.50 Speciosum Magnificum-This variety is much more crimson than the ordinary Rubrum. Price..... .20 2.00 14.00 Speciosum Magnificum-This variety is much more crimson than the ordinary Rubrum-Blooms July and August. Light crimson and white. Petals recurved. Price... .20 2.00 14.00 Speciosum Henryi-The color is rich apricot, flowers reflexed, and come 15 to 20 to stem. Price.... $\mathbf{2 0} \mathbf{2 . 0 0} \mathbf{1 4 . 0 0}$

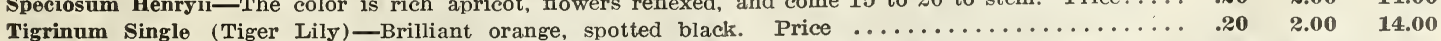
Tigrinum Flora Plena (Double Tiger Lily) - Similar to Tigrinum single. Price ............ .20 2.25 15.00 Leopard Lily (Native Tiger Lily)-Elowers bright orange, dark chocolate spots. Price........ .15 1.50 10.00 Washington Lily-Large native Lily, opening white, gradually shading to a purple. Price....... .35 3.50 1\%.50

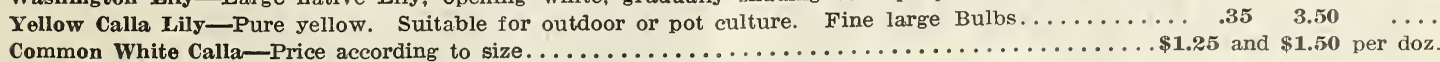




\section{Iris}

All Iris are easy to grow and require very little attention, especially those of the creeping root stock, which are the Fleur de Lis, Flag, and Japanese varieties. The latter require more moisture than the others. There are no importations of English Iris, and Spanish Iris this season. To prevent disappointment it would be advisable to order Spanish Iris early, as we only have a limited stock of California grown.

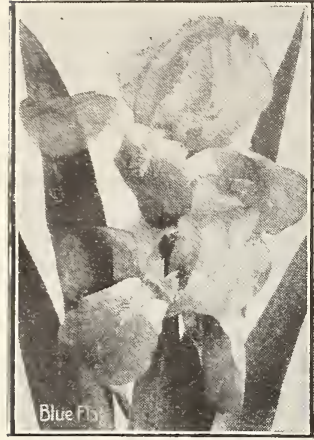

Fleur de Lis and Hybrid Iris

\section{Fleur de Lis and Hybrid Iris}

These come in creeping root stocks which bloom every year and are very early.

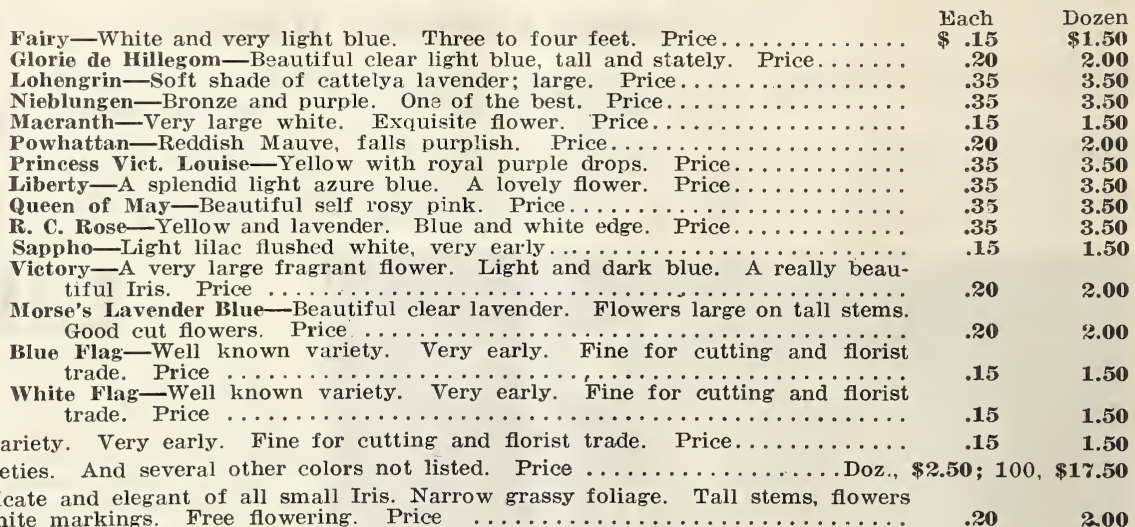

\section{Spanish Iris}

There is a limited supply of this beautiful little Iris this season and consequently we have only a few varieties to offer, but they are good sound stock.

Belle Chinoise - Beautiful golden yellow. Handsome flower. Price; 75e doz.; \$6.00 100 .

King of Blues-Rich dark blue. Shaded light blue. Price, 75e doz.; \$6.00 100.

L'Innocence-Pure white. Price, 75c doz.; $\$ 6.00100$.

Reconnaissance-Bronze and orange blended. Very showy. Price, 75c doz.; \$6.00 100. Morse's Mixed-Mixture of the above varieties, equally balanced. Price, 75e doz.; $\$ 6.00100$

Dozen prices postpaid. Weight per 100, $1 \mathrm{lb}$.

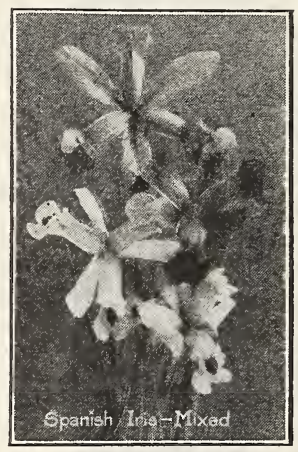

\section{Japanese Iris}

\section{(IRIS KAEMPFERI)}

This is recognized as one of the best Iris in cultivation. It comes in wonderful colors of blues, lavenders, crimson, rose and lilac, as well as the darker shades. They are very hardy and very easily grown, but require quite a good deal of water. Should be planted four inches deep, and twelve to fourteen inches inches deep, and twelve to fourteen inches
apart. Blossoms are often ten inches in diameter and borne on long graceful stems. Ready for delivery in December. If wanted by mail, allow six pounds per dozen for weight.

Put up in separate colors, 50c each; $\$ 5.00$ doz.

Mixture of all varieties and of our selection. Price, doz. \$3.50.

\section{Begonias}

The tuberous rooted Begonias are too well known to need much description, but our improved varieties are far superior to stock usually offered. The fringed varieties are becoming great favorites and all varieties listed are excellent stock for pot culture and bedding purposes. January delivery. Prices are postpaid.

Frilled Variety-These have wonderfully frilled edges and come in all shades of red, pink, salmon, and also white. Any color at 30e each, \$3.25 dozen, or mixed at $\$ 3.25$ dozen.

Double Variety-Flowers come in the same shades as the frilled. These doubles have immense flowers and look like enormous Carnations when in full bloom. Any color at 40 e each; $\$ 4.00$ dozen, or mixed at $\$ 4.00$ dozen

Single Variety-Also supplied in the same shades as the others. The Pinks in this variety are the finest we have ever stocked. Any color at 30c each, \$3.00 dozen, or mixed at $\$ 3.00$ dozen.

\section{Crocus}

Crocus are of very easy culture. Beautiful upright bell shaped flowers, with grass like foliage and very early. They are at home if planted in grass plots or Lawns and make fine borders and potted plants. Can also be grown beautifully in jardinieres with Morse's Bulb Fibre. Plant about three inches deep and as thick as you like. They are never out of place. Dozen prices are postpaid. 100 Bulbs, add $10 \mathrm{c}$ extra postage.

Kathleen Parlow-Very large pure white with orange anthers $\ldots \ldots \ldots \ldots \ldots \ldots$. Madam Melba-Light blue with darker stripes

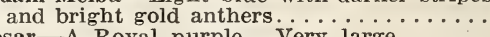

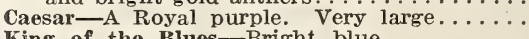
King of the Blues-Bright blue..........

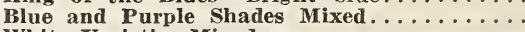
White Varieties Mixed. . . . . . . . . . . . .

Yellow Varieties Mixed .................

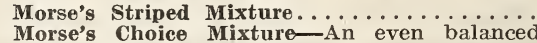
mixture of all varieties, many of them not listed here. Fine for border planting....
Doz. 100

$\$ .45 \$ 3.00$

$.45 \quad 3.00$

.453 .00

$.25 \quad 1.75$

$.25 \quad 1.75$

.25 $\begin{array}{ll}.25 & 1.75 \\ .25 & 1.75\end{array}$ 


\section{Morse's Late Flowering Gladioli}

Our list of late Flowering Gladioli contains one of the best collections we have ever offered. IVhile some of the varieties are older, well known sorts, others are the latest creations. Together, our customers will find the list well balanced in color and shades. Being grown under our own supervision, we knov that all these varieties will give entire satisfaction. No flower is more beautiful and none does hetter in our California climate than the Gladioli.

We are listing these in our Fall Bulb catalog this season so that our customers will get the list early and save disappointment as often is the case when orders arrive too late. Same will also be listed in our Garden Guide which will be issued later in the Fall.

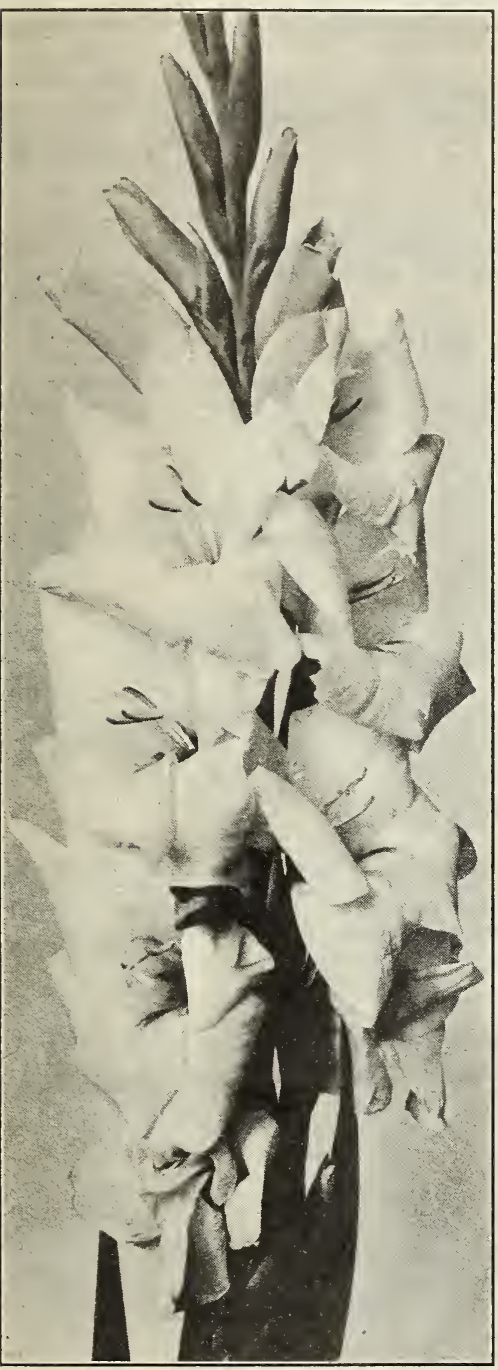

Byron L. Smith

Peace-This is a beautiful variety with fine large white flowers, with pale catealya like feathering on petals....

Prince of Wales-Warm light salmon. Early variety and one of the most beautiful of these shades we know of

\begin{tabular}{lll|l}
.20 & 2.00 & $\mathbf{1 4 . 0 0}$ & A truly wonderful
\end{tabular}

Morse's Special Mixed Gladioli-This mixture is made up of fine selected stock from named varietie recommend same to our customers who require Gladioli in all colors. Dozen, \$1.00. Per 100, \$7.50.

Common Mixture-Made up from a good assortment of cheaper varieties especially adapted for massing, etc. $\$ 0.75$ per Dozen $\$ 5.00$ per 100 .

Our Early Flowering and Primulinus Hybrid types will be found listed on page 2 .
CULTURE: Set bulbs three to four inches deep and seven or eight inches apart. If wanted by mail add extra for postage at the rate of $11 / 1 \mathrm{lbs}$. per dozen.

America-Very popular variety. Flowers soft lavender pink. Well known florists' variety ............. .07 $\$$.75 $\$ \mathbf{\$ 5 . 0 0}$

Baltimore-Color beautiful coral pink, dark blotch at

throat. Very large flowers $\ldots \ldots \ldots \ldots \ldots \ldots \ldots$

Byron L. Smith (New)-Very beautiful true orchid color.
A magnificent variety entirely new ....................

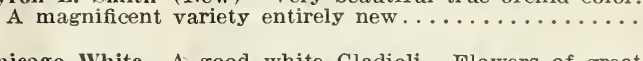

hicago White-A good white Gladioli. Flowers of great
substance and an unusually good keeper. We recommend

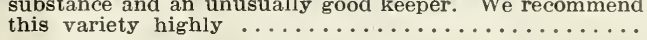

Gretchen Zang-Beautiful soft shell pink blending into scarlet on lower petals. This is a beautiful variety and

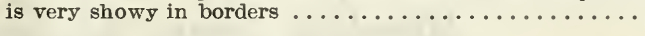

Golden King-Rich golden yellow with crimson blotch. This

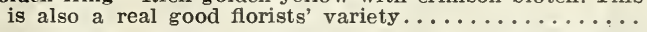

Grandeur (New)-Very large red. Improvement over all

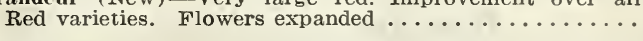

Baron Joseph Hulot (Blue King) - The best blue Gladioli. Rich Indigo Blue. Much superior to Blue Jay. Do not

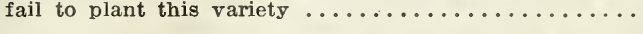

Halley-Delicate salmon. And blossoms early. This is a

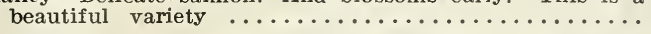

Herada-Pure mauve, and of a most striking, stately flower. Color that is not often found in the Gladioli..

Ida Van-Flaming orange pink or deep salmon. Beautiful

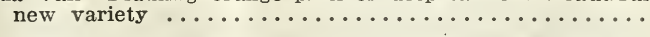

Liebesfeur (Love's Fire) - Bright coral shade. This is one of the best and in appearance is well worth the name

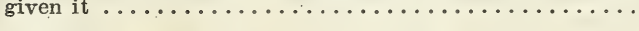

Mrs. Francis King-Well known variety. Flame color.

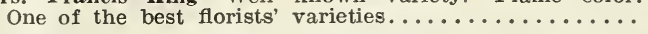

Mrs. Frank Pendleton-Rose pink, shading deeper to center

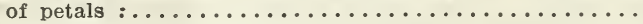

Myrtle-Light pink shaded, color of Spring Arbutus. Very Mrs. Watt-Deep wine color. This is one of the most beautiful varieties we know of. The shade is unique..

Niagara-Extra fine light yellow. Flowers very large on

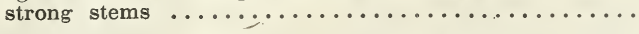

Panama-We can highly recommend Panama as a good companion to America for the florists' trade. Color deep

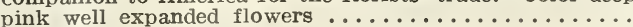

$\begin{array}{lll}.15 & 1.50 & 10.00\end{array}$

.35

3.50

.08

.85

6.00

2.00

14.00

$1.50 \quad 10.00$

$2.00 \quad 14.00$

1.00

$\mathbf{7 . 5 0}$

$.07 \quad .75$

5.00

.20

$2.00 \quad 15.00$

1.50

10.00

$2.00 \quad 14.00$ Schwaben-Primrose yellow, with dark blotch of brownish red in throat.... $\begin{array}{lll}.15 & 1.50 & 10.00\end{array}$ 


\section{Allium}

Molly or Golden Alliun-This little flower is very fine for naturalizing in the Garden. Forms nice clumps of small golden yellow flowers which bloom in June. Per dozen, \$0.50. Per 100, \$3.00.

Neapolitanum-This is the common white starry variety, and is extremely pretty and very hardy. Both varieties grow well in pots. Price per dozen \$0.50. Per $100 \$ \mathbf{\$ 3 . 0 0}$ postpaid.

\section{Agapanthus Umbellatus (Blue African Lily)}

Agapanthus-These beautiful blue flowers are not grown enough. They are so easy to grow if planted in partial shade. Flowers borne in clusters of twenty and thirty. Ready for delivery in November. Price, each \$0.30. Per dozen, \$3.00. If wanted by mail, allow $11 \frac{1}{2}$ lbs. each, extra.

\section{Amaryllis}

We have some different varieties to offer this season, as our descriptions below show. Frequent disturbance of the Amaryllis roots should be avoided, as this prevents free flowering. If wanted by mail, add extra eight lbs. per dozen.

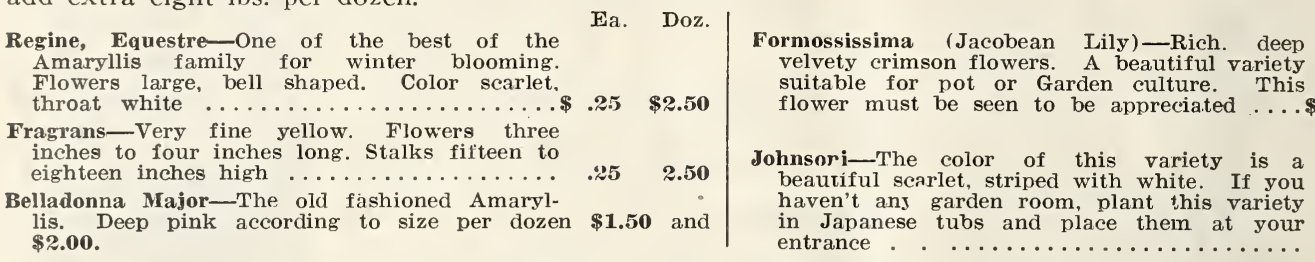
Ea. Doz. egine, Equestre-One of the best of the Amaryllis family for winter blooming.

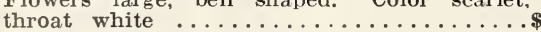
ragrans-Very fine yellow. Flowers three inches to four inches long. Stalks fifteen to lladonna Major-The old fashioned Amaryllis. $\$ 2.00$.

\section{Alstromeria (Peruvian Golden Lily)}

This is the beautiful golden spotted Peruvian Lily you see so often in the florist, windows. We have procured some of the finest stock of this variety in America, and no garder should be without them. They make wonderful cut flowers, keeping from eight to ten days in water. Price \$0.25 each. \$2.50 per dozen. Postpaid.

\section{Bleeding Heart (or Dielytra)}

Eximia-This variety is a great improvement over the Formosa, the well known California variety. Color, reddish purple, drooping habit with two spurs somewhat incurved. Fern like leaves which are very ornamental. Price each \$0.75. Per dozen \$\%.50.

\section{Brodiaea (California Wild Flower)}

A genus of very pretty half-hardy bulbs, with small tubular flowers, borne in large clusters or umbels. The leaves are rush-like, and are excellent for naturalizing pot or garden growing. Following prices are postpaid.

Coccinea-Color is bright red tipped with pea green.

Capitata-Color lovely nale lilac. Fine for borders.

Laxa-Color bright purple.

Price. Doz.

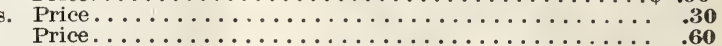

Supplied in mixtures of all three varieties.

\section{Calochortus (California Wild Flower)}

Amabilis (Golden Bell) — These are delightful little flowers with drooping ball-like heads. Yellow. Price....\$.30 \$2.00

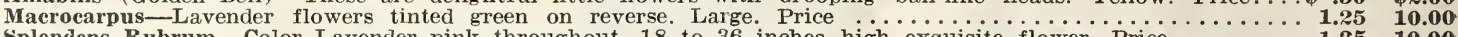

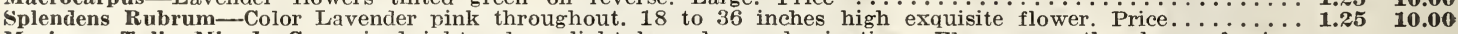

Mariposa Tulip Mixed-Come in bright colors, light lavender predominating. Flowers are the shape of min-

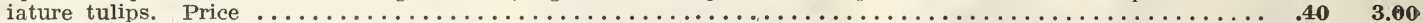

\section{Cannas}

Although the Canna is not a bulb it is always associated with bulbs, so we are listing them in our Bulb Catalogue this season. We have some of the better varieties to offer this year, and as an ornamental garden plant, they are unsurpassed. For large groups on lawns, or planting against fences or unsightly places, they have no equal in the list of ornamental plants.

Allemania-Green leaf variety. Flowers a brilliant orange spotted and mottled with deep orange red $\ldots \ldots \ldots \ldots \ldots \ldots \ldots \ldots \ldots \ldots$

Faisen Dore-Bronze leaves. Full truss of medium size flowers. Colors Apricot salmon. Price

King Humbert-Probably the most popular Can$\mathrm{na}$ there is. Bronze foliage. Immense flowers of brilliant orange red. Streaked with gold.

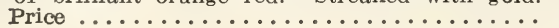

Rosea Gigantea-Green leaf. Color beautiful rosy pink with rounded petals and full truss.

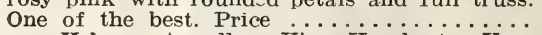
Queen Helene-A yellow King Humbert. V Very floriferous. Rich golden yellow and spotted heavily vermillion. Price $\ldots \ldots \ldots \ldots \ldots \ldots$

Wyoming-Bronze leaf. Large flower and fine shape. Salmon without red. One of the most beautiful varieties we know of. Do not fail

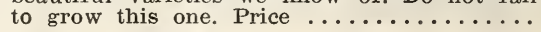
Ea. Doz. $.25 \quad 2.50$ $.25 \quad 2.50$ $.25 \quad 2.50$ If wanted by mail, add $1 \mathrm{lb}$. per dozen, and 5 lbs. per 100

\section{Cyclamen}

December delivery. Prices are postpaid. Beautiful winter greenhouse pot plant. Set with bulb just below the surface, and use only good loam and soil. They come in the following colors: Rose-White-Crimson-Lavender-And all varieties mixed. At \$ .25 each. \$2.00 per dozen.

\section{Caladiums (or Elephant's Ears)}

Caladiums are large leaf plants without flowers, which give a tropical appearance to the home garden. They are most effective for unsightly corners, etc. Price \$.30 each. \$300 per dozen.

If wanted by mail add postage at rate of 8 lbs. per dozen. 


\section{Fritilaria Recurva}

Showy flowers for the garden. Bright scarlet perianth, segments recurved. About two feet high. A very distinct and beautiful flower. Price \$.90 per dozen. \$6.00 per 100. Postpaid.

\section{Gloxinias}

December delivery. Beautiful bell shaped flowers. Spotted and marked in the most beautiful colorings. Their lovely marked foliage is admired almost as much as the beautiful flowers. Nearly all the Gloxinias are natives of South America. Make good potted plants. Prices postpaid.

Ea. Doz. D. Ea. Doz.

Emperor Frederick-Red with white border..\$.40 $\$ \mathbf{\$ 4 . 0 0}$ Royal Purple-Bright purple $\ldots \ldots \ldots \ldots \ldots$...... $\$$ \$4.00

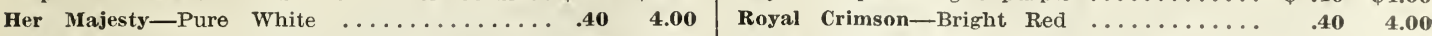

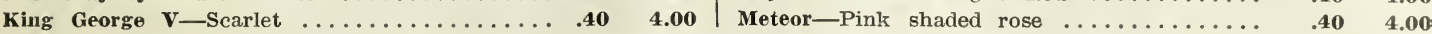

\section{Hyacinths Candicans (or Cape Hyacinths)}

A snow white summer flowering Hyacinth, growing three to five feet in height. Gracefully surmounted with from twenty to thirty pure white miniature bell shape flowers. Price $\$ .25$ each, $\$ 2.50$ per dozen. Postpaid.

Japanese Anemone-As there aren't any importations of bulbous Anemones this season. we are offering the beautiful Japanese Perennial Anemone which come Lavender. Pink. White. The flowers are single, similar to the Holland Pink, White. The flowers are single, similar to the Holland
Single variety. Price $\$ \mathbf{3 0}$ each. $\$ 3.00$ per dozen. OfSingle variety. Price
fered in mixed only.

Montbretias-Bloom early in the summer. They are very desirable for California climate and make one of the best cut flowers we know of, keeping two weeks in water. cut flowers we know of, keeping two weeks in water.
Color beautiful golden bronze. Variety Morse's California. Price \$ .40 per dozen. \$2.50 per 100 . Postpaid.

Peony-The Peony is of exceedingly easy culture. They are seldom attacked by insect or disease and very hardy. Partial shade is most suitable where they can procure plenty of water. Planted between trees or shrubs. We have some of the new shades in Light Pink, Deep Pink, White, Red, and Pink and Lavender. Price \$ .75 each.\$7.50 per dozen. Postpaid.

In roots 3 to 5 eyes each.

Tuberoses-Double Dwarf Pearl Tuberose. Are pure white, wax like and extremely fragrant. Thrive well in warm, sheltered locations. Should be in every garden. Ready February and March. Price \$.90 per dozen. \$6.00 per 100. If wanted by mail. add $1 \frac{1 / 2}{1 b s}$. per dozen. 7 lbs. per 100 .

Lily of The Valley-For many years we have been unable to import any good Lily of the Valley, but this year we will have considerable quantities. The pure white fragrant flowers and pale green foliage of this plant render it one of the most beautiful and most admired. They succeed well in any soil, but prefer shady location Price $\$ 75$ per dozen, \$6.00 per 100 . Prices postpaid.

oxalis-Beautiful little half trailing or bushy plants. Fine for pot, hanging baskets and borders. Flowers all spring and summer. The Grand Duchess variety comes in PinkWhite-Lavender-Yellow. Price \$ .30 per dozen. \$2.00 per 100. Postpaid. The Bermuda Buttereup variety is so well known it needs no description. At same price.

Snowflakes (Leucojum Vernum)-Very early and fine for cutting. Flowers white with green tip; pendant. Very similar to the English Snowdrops, only much longer stems. Price $\$ .50$ per dozen. \$3.50 per 100 . \$32.50 per 1000 . If wanted by mail, add $1 \mathrm{lb}$, per dozen, $5 \mathrm{lbs}$. per 100 .

Watsonias-They resemble Gladioli in general appearance, having tall spikes and flowers in twos. We have some new colors this season and our mixture of Whites, Pinks and Lavenders are the best we have ever had.

Morse's Special Mixture (All Colors)-Price $\$ .75$ per dozen $\$ 5.00$ per 100

Morse's Improved Giant White-Price \$ .75 per dozen, \$5.00 per 100.

Common White-Price \$ .40 per dozen. \$2.50 per 100 .

If wanted by mail add 11/2 lb. per dozen; 10 lbs. per 100 .

\section{Morse's Dahlia Collections}

We have not heretofore listed our Dahlia Collections in the Fall Bulb Catalogue. But many people receive this catalogue about the time that Dahlias are at their best and we have received numerous inquiries, with regards to same at this season of the year. We will not list all our named varieties here, but can assure our customers that practically every variety can be supplied by us if the order is given early. Our full list of named varieties will appear in our General Garden Guide, which will be issued later. Any orders for Collections placed with us early in the season will prevent disappointment in varieties, as the three collections of Dahlias we put out have always met with great approval by our customers. Prices are postpaid to 4th Zone.

Morse's Home Garden Collection-One of the best collections for the Garden at a very reasonable price. Twelve good varieties, our selection. Price \$4.00.

Morse's Special Dahlia Collection-This contains twelve excellent varieties of new high priced Tubers. Nothing but the best in well balanced colors. Our selection. Price \$5.00 per dozen.

Morse's Extraordinary Dahlia Collection-This contains twelve $\$ 1.00$ varieties and twelve $\$ 2.00$ varieties. Express prepaid to 4 th zone. Prize $\$ 30.00$.

\section{Lilium Regale or Myriophyllum}

\author{
Rare Lily from China.
}

Mr. E. H. Wilson, the famous plant collector, who brought these original bulbs from $\mathbf{N}$. W. China, considers this the finest of all Lilies. It is absolutely hardy and excellent for forcing. It has been predicted that this will become the Easter Lily of the future. The flowers are White and slightly suffused with Pink, with a beautiful shade of Canary Yellow at the Center. Awarded Gold Medal by the Mass. Hort. Society and 1st Class Certificate at the Royal Mass. Hort. Society and 1st Class Certificate at the Royal $\$ 1.00$ each, postpaid.

\section{Ranunculus}

Ranunculus are very scarce this year, owing to the embargo on them from Holland, but we have been fortunate in procuring some California grown stock, which we feel sure will give satisfaction.

They come in mixture only, of both light and dark colors at $\$ .50$ per dozen. $\$ 3.50$ per 100 , postpaid. 


\section{Morse's Early Flowering Long Spencer Sweet Peas}

These comparatively new Sweet Peas are making more friends each season, and they merit all the success they are receiving. Weeks before the later types come into blossom, these Earlies are out on their vines in all their wealth of colors.

Also Morse's New Early Flowering Long Season Spencers are just the peas for tropical countries, and are often the only Sweet Peas which will flower in the tropics.

The Sweet Pea is the great favorite flower for all gardens, and these new sorts are among the best for fragrance, size and beauty, and are fully as large as the splendid later kinds.

Seed planted in early September in San Francisco, will produce flowers about Christmas time. Seed planted in October and November will have fine large flowers in February and March.

We do not mean that these New Early Sweet Peas should take the place of the magnificent Late Flowering Spencers, but they are an addition to the garden of those who wish flowers early and late. Many growers of the Early Flowering Sweet Peas have written us telling of the wonderful success with these varieties. Among many others is one from Mr. C. H. Sarcander of San Bruno, San Mateo County, Calif., who writes in part, under date of June 15th, 1921:

"Last September I planted several varieties of your Early Flowering Sweet Peas, Early Songbird-Early MelodyEarly Songster-Early Liberty. They have been in bloom four months and are still full of flowers. Many of the vines are ten feet high, etc., etc."

Also Mrs. A. H. Nicholls, 675 College Avenue, Fresno, Calif., writes under date of June 3rd, last:

"I planted an eleven foot row of your Early Flowering Sweet Peas in October, last. They commenced to bloom the middle of February and I have gathered over 3500 stems of flowers to date. Often four to the stem. They have grown so tall they reach the roof of my house, and are still blooming and I am cutting over 300 stems per week now, etc., etc.,"

These varieties should be grown more extensively in the Home Garden and especially for the florists' trade. We have one new introduction to offer this season in addition to our 1921 and former lists.

1922 Novelty

\section{Early Merry May}

A soft light pleasing combination of Apricot and Pink. Color is very light on the wings, but deeper in the standard, sometimes quite fully colored. In the bunch the effect is beautiful. In form, size and vigor, we think it one of the best. Price per packet $\$$.25.

Early Congo-Chocolate color. Makes a fine contrast with the lighter colors. Pkt. \$.i5.

Early Harmony-Giant new Lavender. Perfect flowers and long stem. Pkt. \$.15.

Early Hercules-Giant flower of finest form. Color is bright rose pink on white ground. Pkt. \$.15.

Early Heatherbell-Color rich pleasing mauve, but after standing in water, turns beautiful lavender. Pkt. \$ .15.

Early Liberty-Deep sunproof crimson. Color of King Edward Spencer. Large flowers. Pkt. \$.15.

Early Meadowlark-Deep, rich, cream. Many flowers are duplex, and extra waved. Pkt. $\$ .15$.

Early Melody-A beautiful bright pink, resembling Countess Spencer. Long stems. Pkt. \$ .15.

Early Morning Star-Deep orange scarlet, or flame color. The best orange shade variety. Pkt. $\$ .15$.

Early Nightingale-Beautiful mauve lavender, turning to blue-lavender in water. Plrt. $\$ \mathbf{. 1 5}$.

Early Robin Red Breast-Orange salmon. Very large flower, good florists' variety. Pkt. \$.15.

Early Snowflake-White as snow. Very long stem variety, of beautiful form. Pkt. $\$$.15.

Early Songster-Pale lavender. Color of Masterpiece. Pkt. $\$ .15$.

Early Songbird-A splendid light pink. Very pretty and extremely well waved. Pkt. \$.15.

Early Spring Maid-Light flesh pink. Very much like Mrs. Hugh Dickson. Pkt. \$ .15.

Early Pink and White-A bright bi-color similar to the fine variety, Blanche Ferry. Pkt. \$ .15.

Early Peace-Giant, cream, pink variety. Color deeper than Spring Maid. Pkt. \$.20.

Early Torch-An orange scarlet that will not burn in sunlight. One of the best. Pkt. \$.15.

Early Warbler-Color is rich mauve purple. Flowers extra large and well formed. Pkt. \$.15.

Yarrawa-Rose changing light pink standard. Pkt. $\$ .15$.

Collection of Morse's Early Flowering Sweet Peas-One packet of each kind, 20 varieties, including our 1922 Novelty, Early Merry May. Price \$2.75.

Our Late Flowering Spencers listed on next page.

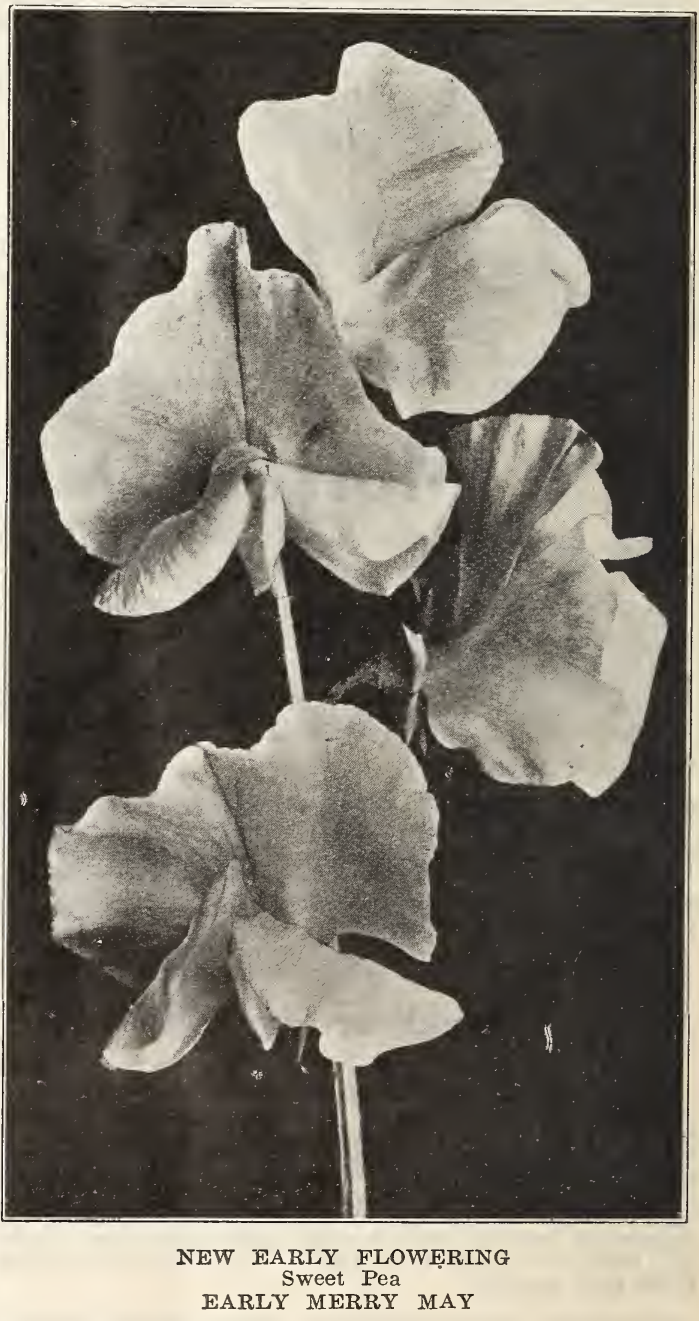

Index to this Catalog See Inside of Back Cover 


\section{Morse's "Grand Prize" Sweet Peas}

We are known the world over as the Largest and Best Growers of Sweet Peas

\section{Collections of Superb Sweet Peas}

We put our finest Sweet Peas in these collections in a wide range of colors. Our own Selection.

MORSE'S EXTRAORDINARY SPENCER COLLECTION 35 VARIETIES for \$2.50,.including most of the finest sorts.

MORSE'S "MEDAL OF HONOR." This has 10 of the fine Spencer varieties used in winning the Medal of Honor at P. P. I. E. Price \$.75.

MORSE'S “GRAND PRIZE” COLLECTION. We have put 15 of our best Spencer Varieties in this collection. Price $\$ 1.00$.

\section{Morse's Superb Spencer Sweet Peas}

All of the Most Glorious Flowers with truly Giant Blossoms are our Spencer Sweet Peas. All have three or four immense blossoms to a stem.

\section{Morse's Sweet Pea Novelties for 1922}

Mrs. Tom Jones-For some time we have been looking for a real Blue Sweet Pea, and in this one we have it. The plants are strong, vigorous growers, producing huge flowers usually four to a stem. Color is bright Delphinium Blue. Price per packet 25e.

Hawlmark Pink-A novelty imported from England, and although it seems impossible that there could be anything new in pink sweet peas, nevertheless, here it is. The beautiful coloring is what we would describe as a Pelargonium Pink, deeper on the niargin of the standard, and cheeks of the petals, blending off lightly to the throat. Large flowers, long stems, and unquestionably the most beautiful pink Sweet Pea. Price per packet 25c.

Royal Scot-Of all brilliant, scarlet shades of Sweet Peas sent out by either this country or Great Britain, none surpass "Royal Scot." In size and form, it is far superior to any other of this shade, and does not fade or burn in the

hottest sunshine. One of the best recent novelties. Packet 25c.

White Pkt. Oz.

Constance Hinton-A very large white Spencer. $\$ . \mathbf{1 0} \$ \mathbf{. 5 0}$

Etta Dyke-Large pure white..............10 $\mathbf{. 5 0}$

King White-A giant white ..............10

White Spencer-Morse's Re-selected, a superior strain of the very finest Spencer..........

\section{Cream Pink Shades}

Doris Usher-Light saimon pink ........... 10

Margaret Atlee-Beautiful deep cream pink ....

Mrs. C. W. Breadmore-Primrose with pink edges .10

Mrs. Hugh Dickson-Buff, Apricot and Rose.... .10

Mrs. Routzahn-Apricot, pink and straw color.. $\mathbf{. 1 0}$

New Miriam Beaver-Soft shell pink and salmon. $\mathbf{. 1 0}$

W. T. Hutchins-Buff and light primrose.......

\section{Pink Shades}

Countess Spencer-Clear pink ............. Dainty Spencer-White with rose-pink edges.... Elfrida Pearson-Light pink, shaded lighter .... Florence Morse Spencer-White \& blush pink edge Hercules - Clear pink, larger than Countess Spencer ........................10

Primrose, Cream or Ivory Shades

Clara Curtis-Large, wavy cream, or light prim-

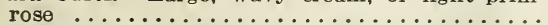

Dobbie's Cream-Large and fine; deep cream.....

Paradise Ivory-Light primrose with slight tint

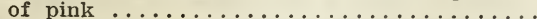

Primrose Spencer-Clear primrose, white seeded..

Rose and Very Light Pink-Bi-Color

Apple Blossom Spencer-Standard bright rose, wings primrose, with flush of rose.........

Mrs. Cuthbertson-Giant flowered rose and light

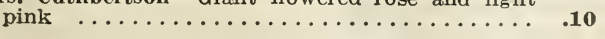

Red Shades

Gaiety Spencer-Bright rose-crimson striped and flaked on ivory white.............. King Edward Spencer-Best pure red Spencer...
Red Shades-(Continued) $\ldots \$ .10 \$ .50$ Vermillion Brilliant-Pure scarlet............10

\section{Lavender Shades}

Asta Ohn-Soft. pinkish lavender self. Large. . $\mathbf{. 1 0} \mathbf{. 5 0}$ Blue Picotee-White, with edging of blue...... $.10 \quad .50$ .50 Dobbie's Lavender Geo. Herbert-Fine lavender. Bluish after standing in water............. Flora Norton Spencer-Bright blue............10 Masterpiece-Large wavy lavender, tinted mauve $\mathbf{. 1 0} \mathbf{. 5 0}$ New Margaret Madison-Best azure blue..... Wedgewood-Larger than Zephyr; silvery blue..

\section{Blue and Purple Shades}

Helen Pierce Spencer-Marbled blue on white.... $\mathbf{1 0} \quad .50$ Senator Spencer-Chocolate and brown striped.. $\quad .10 \quad .50$

Deep Maroon, Purple and Blue Shades

Nubian-Largest and deepest maroon..........10 $\quad . \mathbf{. 5 0}$ Othello Spencer-Deep rich maroon, very dark. . Royal Purple-Rich royal purple............ Warrior-Rich maroon. Flowers of extra size.. $\quad . \mathbf{1 0} \quad \mathbf{5 0}$

\section{Orange and Salmon Pink Shades}

Aurora Spencer-Bright orange-pink striped.... $\quad .10 \quad .50$ Barbara-Bright salmon orange with dark stems $\quad .10 \quad .60$ Helen Lewis-Orange pink, with orange standard $\mathbf{. 1 0} \mathbf{. 5 0}$ Illuminator-Brilliant orange-searlet $\ldots \ldots \ldots \ldots, \quad .10 \quad .60$

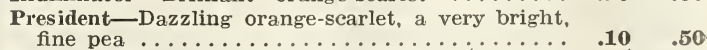
Robert Sydenham-Great English pea, orange

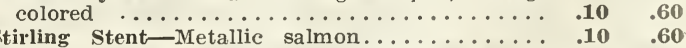
Thos. Stevenson-Giant flame-colored Spencer..

Morse's Superb Spencer Mixture of Sweet Peas-This mixture is made up from our carefully prepared formula. It contains practically all the true Spencer varieties introduced to date. Price, pkt., 10c; oz., 30c; 1/4lb., 90c; 1 lb., $\$ 3.00$. 


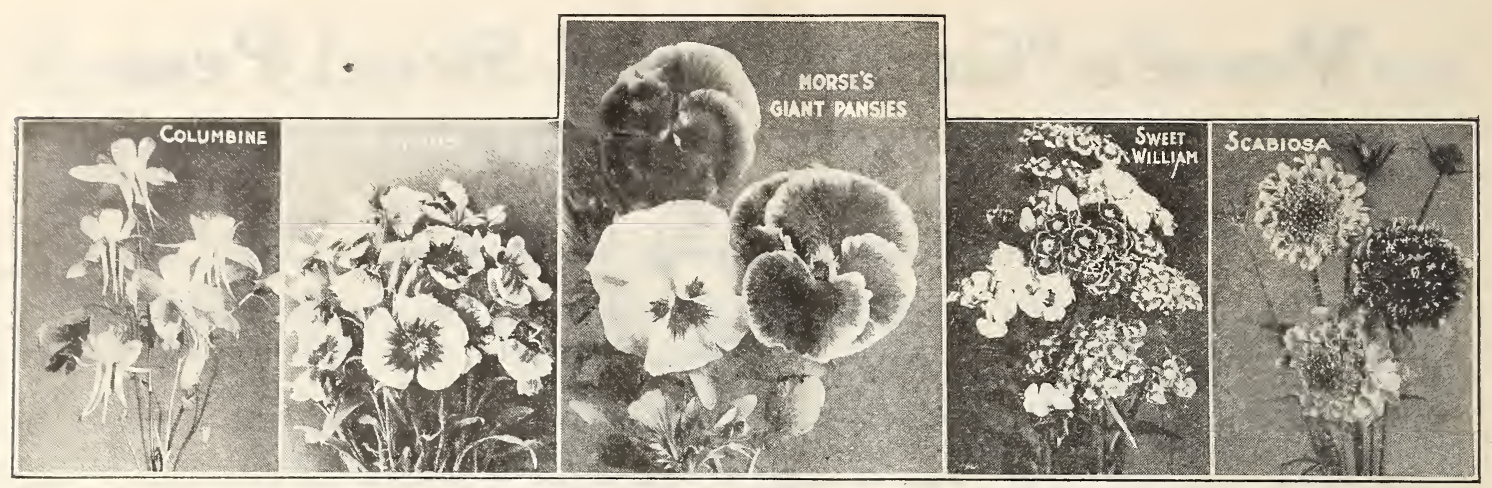

\section{Flower Seeds and Perennial Roots that Should be Planted in Fall}

Fall planting should be done much more largely than is generally supposed. If you are to have a continuous display of bloom in the garden next summer, you must start the young plants now. They will not bloom during the winter, but they will make thrifty plants, which will come into flower much earlier than if they had been sown in the spring. Plants which will flower during the winter time are not numerous. Some of the best of these are: Calendula, often called Cape Marigold; Stocks, Cornflower, Pansies, Winter Flowering Sweet Peas, Snapdragons and Wallflowers, There are also several bulbs which bloom particularly early, namely: Narcissus, Paper White Grandiflora, Freesias and Snowflaikes. These come two months before the other bulbs if they are set out early.

If annual plants are started six weeks before cold weather they will stand winter frosts without being damaged. While it is advisable to sow hardy annuals in the fall, they may also be planted in the spring. In the interior valleys, where the summer is dry and hot, they will be much better if planted now-that is, before December.

Complete descriptions of the following may be had from our Garden Guide. If you have lost your copy which we sent this spring, we will gladly send another.

Anchusia (Italica) - Deep blue Four feet tall... Alyssum (Little Gem)-Pure white border flower.

Alyssum (Common Sweet) - Pure white. Twelve inches Auricula (Primula)-Alpine Primrose. Eight inches. Bartonia Aurea-Handsome yellow wildflower. Bellis Perennis-Double Mixed English Lawn Daisy.. Bellis Perennis Longfellow-Large pink.

Bellis Perennis Snowball-Pure white.

Calendula-Yellow and orange; free bloomer

Calliopsis-Mixed

Carnation (Marguerite) - In white, pink, red and mixed Centaurea (Cyanus)-Blue and mixed.

Centaurea (Imperialis) - Very large fine cut flower. Purple and white

Clarkia-Good bedding plants; double and single. Collinsia-Purple and white. California wildflower Coreopsis-Excellent yellow cut flower.

Columbine-Hybrida mixed

Columbine-Long spurred hybrids.

Daisy (Shasta) -Pure white, very large flower

Dianthus Heddewigi-Single mixed, Japanese mixed, double mixed

Dianthus (Grass Pink) - Silver leaf Single and double Eschscholtzia (California Poppy) - Yellow, deep orange, crimson and white

Digitalis (Fox Glove) -Purple, rose, white, mixed.

Four O'Clock-Old fashioned trumpet shaped flowers in

all colors

Forget-Me-Not-Blue, white and pink.

Gaillardia-Double and single varieties.

Godetia-Tall and dwarf varieties mixed

Godetia_Double varieties mixed.

Gypsophila (Baby Breath) - Small white flowers

Gypsophila (Paniculata)

Hollyhock-Tall double mixed.

Hollyhock-Morse's Giant single mixed

Larkspur-All colors

Lavatera-Large single mallow, white and rose.

Linum (Scarlet Flax)-Perennial.

Lobelia-Celestial, Crystal Palace, Snowball.

Lupin-All varieties in assorted colors.

Marigold-Eldorado, tall and dwarf French.

Nemesia-Blue Gem

Nemophila-Light blue wildflower

Oenothera (Evening Primrose)

Pansies-Morse's Prize Strain. The very finest giant sorts. Faced pansies, plain colors and blended sorts.

One of our best mixtures.

Pansies-Bedding varieties, in all colors.

Pentstemon-A wonderful fall flower.

Poppy (Iceland Mixed)-Beautiful shades.

Scabiosa

Snapdragon-All colors, separate or mixed

Sweet William-All shades; double or single.

Stocks Nice-Mixed, Brompton and Ten Weeks.

Wallflower-Yellow and orange shades; double or single
Perennials planted from roots or clumps, at this time of the year, will produce an abundance of flowers next summer. Below is a list of same, which we are pleased to offer. Nothing equals the beautiful effect of perennials in the garden, and for cut flowers they are unsurpassed. Orders for these should be placed a few days before required, to give us time to lift them. This enables us to supply this stock in perfect, fresh condition. If wanted by mail, add 3 cents per clump for postage.

Achillea Tomentosa-Very finest variety........\$ .25

Achillea Ptarmica Pearl-White, true stock....... .20

Aubretias Mixed-From finest named varieties...... .25

Campanula Grosseckii-A beautiful variety........ .20

Campanula Media Mixed-One year field grown...... .20

Campanula Separate Colors-Light blue, dark blue, white and rose...................... .20

Cerastrium Tomentosum-Beautiful garden plant.... .25

Coreopsis Lanceolata-Field grown stock.......... .20

Delphinium-From finest named varieties. In single and double, light and dark blue mixed.......... .25

Cenothera Lamarkiana-Beautiful variety...........20

Oenothera Speciosa-Wonderful strong stock....... .25

Digitalis Lanata-Perennial Fox Glove............25

Gaillardia Kelwayii-The best of its variety....... .20

Geum A Trosanguineum-Best on the market....... .25

Gypsophila Acutifolia $\ldots \ldots \ldots \ldots \ldots \ldots \ldots \ldots \ldots \ldots$.25

Hollyhocks Double-In white, pink, maroon, salmonpink, canary yellow, red and white..............

Hollyhocks Single-In maroon, pink and white. Strong,

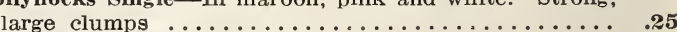

Hollyhocks Mixed-Single and double..........25

Iberis Gibraltarica-Fine, healthy plants..........20

Michaelmas Daisies (Perennial Aster)—Feltham blue, Effie, Wm. Bowman, Tataricus, John Wood........

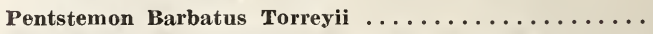

Salvia Azurea Grandiflora-Very strong plants. Should

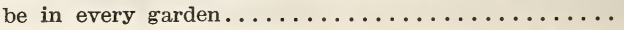

Linaria Dalmatica-Handsome plant with yellow flowers

Phlox Perennial-Peach blow pink; Mrs. Jenkins, white;

Le Mahdi, blue; Gen. V. Heutz, cherry..........

\section{Index to this Catalog See Inside of Back Cover}




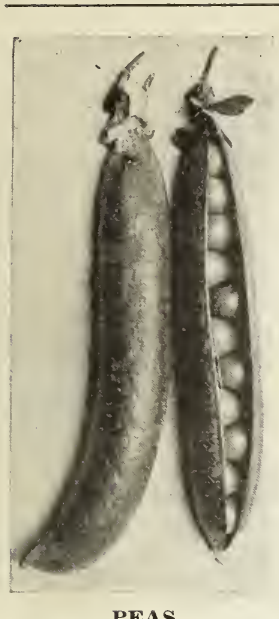

PEAS

Morse's Union Jack

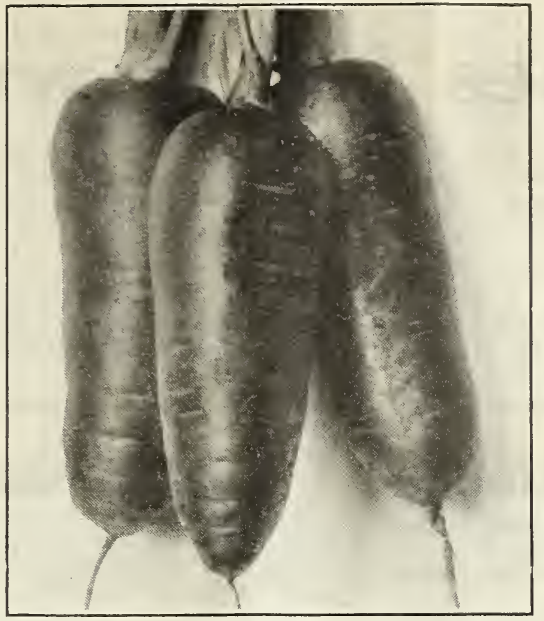

CARROT

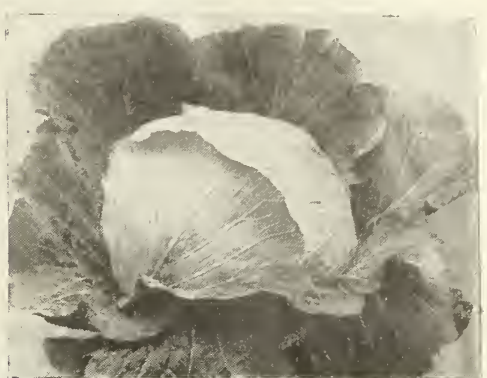

CABBAGE

Morse's Premium Flat Dutch

\section{Vegetables for Fall Planting}

In our wonderful California climate so many of the Vegetables can be planted in the Fall of the year to a great advantage. Below are a few of the vegetables which we recommend for fall planting. Many other varieties are listed in our annual GARDEN GUIDE.

Many varieties of our Improved stock of Table Peas, if planted in protected places, will insure Peas for February picking. They require fairly rich soil, but in locations not too wet for planting at this time of the year. Sow in rows twelve to eighteen inches apart for Dwarf varieties and three feet apart for tall varieties. Prices are postpaid up to and including the fourth zone on all quantities up to $10 \mathrm{lbs}$. Larger quantities are priced F. O. B. San Francisco, California.

Stratagem Morse's Selected - A semi-dwarf variety with large leaves and large pods. Vines bear well and the pods are long, thick, and well filled. Our hand picked stock lb., 30c; 10 lbs., \$2.50; 100 lbs., \$15.00.

Snowdrop (1921 Novelty) - We highly recommend this very fine Pea as a distinct improvement over other types. Grows a light green vine from $3 \frac{1}{2}$ to 4 feet tall and bears a large number of dark blunt pods. Of large size. These contain an average of 7 or 8 large Peas of exceptionally fine quality. Price, pkt., 15c; lb., 30c; 10 lbs, \$2.50; 100 lbs, \$15.00.

Blue Bantam-A wonderful good Pea. This is a medium dwarf variety and in bearing they have very long pods of deep green color. Blue Bantam is a very heavy producer and is tender and unusually sweet when cooked. Price, pkt., 15c; lb., 35c; 10 lbs., 3.00; $100 \mathrm{lbs}, \$ 17.50$. BEETS Pkt. Oz. $1 / 4$ ib 1 ib

Detroit Dark Red-Globe shape, deep red flesh $\ldots \ldots \ldots \ldots \ldots \ldots \ldots \ldots \ldots . .10$. $\$ .20 \$ .40 \$ 1.00$ Morse's Imp. Blood Turnip-Excellent variety ...................... 10 .20 $\quad .40 \quad 1.00$

Morse's Imp. Giobe-Very sweet. Fine texture $\ldots \ldots \ldots \ldots \ldots \ldots \ldots \ldots \ldots \ldots . .10 \quad .20 \quad .40 \quad 1.00$

Morse's Half CARROTS

Iorse's Half Long-The best half-

$\begin{array}{lllllll}\text { long variety } \ldots \ldots \ldots \ldots \ldots \ldots \ldots & \ldots \ldots & .10 & .20 & .40 & 1.00\end{array}$

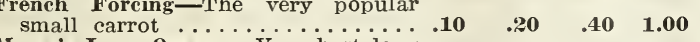

Morse's Long Orange- Very best long variety ....................10 . 20 $\quad .35 \quad .90$

Early Jersey Wakefield-Early pointed head type $\begin{gathered}\text { Danish Ballhead-Good for fall plant- } \\ \text { bo }\end{gathered}$

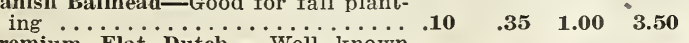
Premium Flat Dutch - Well known late variety ................10 $\quad .35 \quad 1.00 \quad 3.50$

California Wonder_CAULIFLOWER Pkt. 1/4 oz. 1 oz. $1 / 4$ ib

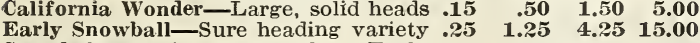
Snowball-A little later than Early

Snowball ................25 $1.25 \quad 4.2515 .00$ ENDIVE Pkt. Oz. $1 / 4$ ib 1 ib

Broad Leaved Batavian-Wide, thick

Broad Leaved Batavian-Wide, thick
leaf variety $\ldots \ldots \ldots \ldots \ldots \ldots \ldots \ldots \ldots$
Green Curled - Well known

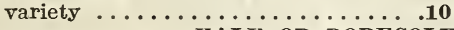
KALE OR BORECOLE Green Curled Scotch-Especially for

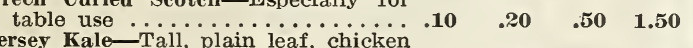
Jersey Kale-Tall, plain leaf, chicken .10
Little Marvel-An extra dwarf Pea which is very prolific. Each pod has six or seven large Peas, well formed in pod. Yields heavier than any other in this class. Very sweet and tender. Price, pkt., 15e; 1b., 35c; 10 lbs., $\$ 3.00 ; 100$ lbs., \$1\%.50.

Union Jack (Another 1921 Novelty)-Union Jack has a curved, pointed pod, well filled with large, sweet peas. Height three feet, and a very strong, vigorous grower. You will find this Pea, like Snowdrop, a decided improvement over the older varieties. These should be planted in every home garden. Price, pkt., 15c; lb., 30c; 10 lbs., $\$ 2.50 ; 100$ lbs., \$15.00.

Dwarf Telephone (or Daisy) - We can highly recommend the Dwarf Telephone for fall planting. Height, about two feet, and vines completely covered with large full bearing pods. Does extremely well in California. Price, pkt., 15c; lb., 40c; 10 lbs., \$3.50; 100 lbs., \$25.00.

$$
\text { LETTUCE Pkt. Oz } 1 / 4 \text { ib } 1 \text { ib }
$$

Big Boston-Delicious large head variety ...................10 \$ .20 \$ .50 $\$ 1.50$ Los Angeles or New York-Popular

market variety $\ldots \ldots \ldots \ldots \ldots \ldots \ldots .10 \quad .25 \quad .75 \quad 2.50$

White Paris $\operatorname{Cos}-$ Best loose leaf
variety $\ldots \ldots \ldots \ldots \ldots \ldots \ldots \ldots .10 \quad .20 \quad .40 \quad 1.25$

Australian Brown - Long keeping

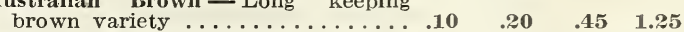

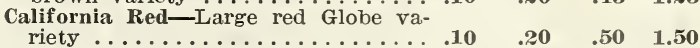

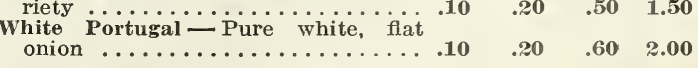

RADISH

$\begin{array}{lllll}\text { Icicle-Mild white variety. One of the } & & & \\ \text { best } & . . & .0 & .45 & 1.25\end{array}$

$\begin{array}{llllll}\text { best } \ldots \ldots \ldots \ldots \ldots \ldots & .20 & .45 & 1.25 \\ \text { Long Scarlet-Fine selected variety. } & .10 & .20 & & \\ \text { Very brittle } \ldots \ldots \ldots \ldots \ldots \ldots \ldots \ldots & .10 & .20 & .40 & 1.00\end{array}$

Siberian-A recent novelty. . . . . .

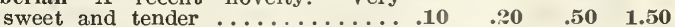

TURNIP

Early White Flat Dutch-One of the

best table sorts ..............10 $\quad .15 \quad .30 \quad .75$

Amber or Yellow Giobe-Large clear

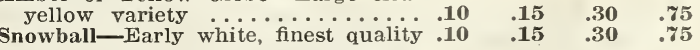
PARSLEY

Morse's Double Curled-Deep rich

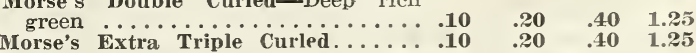
SPINACH

Bloomsdale Savoy - Large round,

thick leaf variety ..............10 $\quad .15 \quad .30 \quad .75$

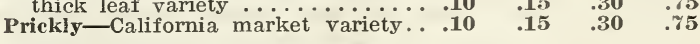




\section{Grasses for Lawns}

Grass Seed for Lawns does well if planted in the Fall, especially in locations where the hot sun has a tendency to scorch the young growth if planted earlier in the season. Planting your Grass Seed in the Fall, you do not require the Seed covered very deep. Prepare the soil well and dig in some GROZ-IT or other Fertilizer. After sowing the Seed, lightly cover with sandy loam or rake the Seed in lightly, and roll down, but not too tight.

It is a good plan to keep a little Seed in hand to sprinkle over your. lawn several times a year immediately after cutting. The use of a little soil mixed with your Seed when renovating, will supply nutriment to the roots which are being constantly washed with repeated watering. Use $1 \mathrm{lb}$. of Seed to 250 sq. ft. of Lawn, with the exception of Morse's White Clover, when use $1 \mathrm{lb}$. to $350 \mathrm{sq}$. ft. of Lawn.

One pound and ten pound prices are postpaid. $100 \mathrm{lb}$. prices, F. O. B. San Francisco. Write for prices for larger quantities than specified here.

\section{Morse's California Lawn Mixture}

A well balanced mixture of Grasses to make a good, fine lawn. Highly recommended where Clover is not required. Price per lb., 70c; 10 lbs., \$6.50; 100 lbs., \$60.00.

\section{Morse's Golden Gate Park Mixture}

A splendid mixture of Grasses containing the right amount of clover, which produces a good, hard sod, as put up by us for many years past. Be sure its Morse's. Per lb., 40c; 10 lbs., \$3.75; 100 lbs., \$35.00.

\section{Morse's Shady Lawn Mixture}

Adapted for partial and shady lawns, especially good for under trees, palms, etc. Price per lb., \$1.00; 10 lbs., \$9.00.

\section{Morse's Pacific Rye Grass}

One of the best Grasses for Lawn in sandy soils, such as around San Francisco. Pacific Rye Grass is much finer leaved than the Australian Rye, but just as hardy. Price per lb., 30c; 10 lbs., \$2.50; 100 lbs., \$20.00.

\section{Morse's Kentucky Blue Grass}

Where you have every condition right there is no Grass that takes the place of Kentucky Blue. It requires plenty of water, warmth and care. And makes a wonderful Lawn. Price per lb., 75c; 10 lbs., $\$ 7.00 ; 100$ lbs., $\$ 65.00$.

\section{Morse's Special White Clover}

This is special recleaned stock and free from weeds. Extra dwarf and fine leaved. Price per lb., \$1.00; 10 lbs., $\$ 9.00 ; 100$ lbs., \$80.00.

Special mixtures put up for SHADY LAWNS, TERRACE AND SLOPES, SANDY LAWNS, SEASIDE LAWṆS, etc. Let us know your requirements.

\section{Golf Course Grasses}

We are prepared to put up all Mixtures for Golf Course requirements to our customers on formula or we will be pleased to quote on our own Special Mixtures for same. We carry a full line of Grass Seeds necessary for this work, and invite correspondence regarding same.

\section{Also permanent Pasture Mixtures for wet and dry locations. Write us for special prices.}

\section{Cover Crops Suitable for Fall Planting}

The planting of leguminous plants to plow under in the Spring, to add Nitrogen to the soil, is being done more extensively now than ever before. To get the full benefit of these crops in this way, these seeds should be inoculated with FARMOGERM, which is supplied for all leguminous crops by us in $1 / 4$ acre bottles, 80c; 1 acre, \$2.00, postpaid; 5 acres, by express, \$8.00. We recommend Purple Vetch as an excellent cover crop. Price 30e lb.; 10 lbs., \$2.75; 100 lbs., \$25.00.

Melilotus Indica (Bitter Clover) - Starts very early and makes good growth during winter. Not good for Hay or Forage. Use twenty to twenty-five lbs. of Seed per acre. Price 20e lb; 15e lb. in $10 \mathrm{lb}$. lots.

Write for prices on larger quantities.

Melilotus Alba (Sweet Clover) - This is the white flowering variety and does well on the poorest of soils. Sow twelve to fifteen lbs. per acre. Price 35e lb.; 2 : $1 \mathrm{lb}$. in $10 \mathrm{lb}$. lots.

Write for prices on larger quantities.

Burr Clover (Medicago Denticulata) - Is one of the best cover crops and does well on dry hillsides. Requires very little water. Sow fifteen to twenty lbs. per acre. Price 30c lb.; $2 \gamma^{1 / 2} \mathrm{e} \mathrm{lb}$. in $10 \mathrm{lb}$. lots.
Spring Veteh (Vicia Sativa)-Large quantities of this variety of Vetch is used as cover crops every year. It is perfectly hardy. Requires from sixty to seventy pounds per acre. Price 20e lb.; 121/2e lb. in $10 \mathrm{lb}$. lots; $100 \mathrm{lbs}$., $\$ 9.00$. Write for prices on larger quantities.

Hairy Veteh (Vieia Villosa)-A much later Vetch than the Spring Vetch, but produces heavier foliage. Should be planted in September and in soil that is of a moist nature or irrigated. Thirty to thirty-five pounds per acre. Price 35e lb.; 25e lb. in $10 \mathrm{lb}$. lots.

Write for prices on larger quantities.

Canada Field Peas-Sow seventy to eighty pounds per acre. This is also excellent forage for cattle, and also as a cover crop. Price $20 \mathrm{e} \mathrm{lb;} \mathrm{121/2 \textrm {e }} \mathrm{lb}$. in $10 \mathrm{lb}$. lots; $100 \mathrm{lbs}$. $\$ 9.00$.

Write for prices on larger quantities.

\section{Alfalfas and Clovers}

Morse's Extra Choice Recleaned Alfalfa-We can highly recommend this grade of Alfalfa as being the best acclimated sort, and recommend it for all-round growing. Price, 50e lb. Larger quantities at market price. Please write us.

Grimm Alfalfa-One of the hardiest strains of Alfalfa. Will withstand the coldest of winters, even in the East. Ours is genuine stock. Sow twelve pounds per acre. Price, $\$ \mathbf{1 . 0 0} \mathrm{lb}$. Special quotations on larger quantities.

Hairy Peruvian Alfalfa-This is one of the very finest varieties for Hay purposes and has an extra amount of foliage and makes wonderful fast growth. Price, 50e lb. Special prices for larger quantities.

Turkestan or Dry Land Alfalfa-Best dry land Alfalfa. Price, 50e lb. Larger quantities quoted.

Red Clover-Sow twelve to fifteen pounds per acre. Price, 50e lb. Larger quantitics quoted. 
W Carry a Splendid Assortment of HYACINTH
GLASSES, LILY BOWLS and JARDINIERES.

The List of Bulbs that can be successfully grown in Morse's Bulb Fibre is given on the inside of front cover, and a cut showing Freesias growing in same is given on page 4.

Hyacinths are very successfully grown in Special Hyacinth Glasses with Water, as shown on page 2.

Hyacinth Glasses - - $\quad-\quad 35 c, 50 c$ and $75 c$ each Lily Bowls - $\quad 50 \mathrm{c}$ to $\$ 2.00$ each according to size Fancy Jardinieres - $\quad$ - $\quad$ 50 to $\$ 5.00$ each

\section{Packed and Shipped by Express at Customer's Own Risk.}

\section{INDEX}

AGAPANTHUS

ALLIUM

ALFALFA

AMARYLLIS

ANEMONE JAPANESE PERENNIAL

ALSTROMERIA (PERUVIAN LILY)

BEGONIAS

BLEEDING HEART

BRODIAEA

CALLA LILIES, WHITE IND YELLOW

CALOCHORTU

CALADIUM

CANNAS

COVER CROPS

CROCUS

CYCLAMEN

CULTURE FOR BULBS

DAFFODILS, CROWN VARIETIES

DAFFODILS, DOUBLE VARIETIES

DAHLIA COLLECTIONS

FIBRE FOR BULB GROWING........ Inside of Front Cover

FREESIAS, ALL COLORS.............. 4

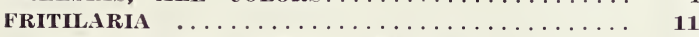

FLOWER SEED FOR FALL PLANTING......... 11

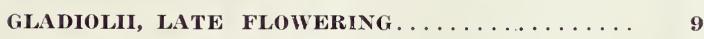

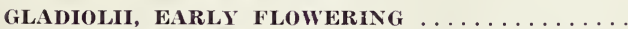

GLADIOLII, PRIMULINUS .............

GLOXINIAS

IIYACINTHS, PREPARED

HYACINTHS, SINGLE NAWED FIRST SIZE

IY ACINTHS, DOUBLE

HYACINTHS, INTERMEDIATE

HYACINTHS, BEDDING

HYACINTHS, CANDICANS

10

16

10

11

10

8

10

10

7

10

10

10

16

8

8

\section{PAGE}

$P$

$\frac{1}{6} \mathrm{r}$




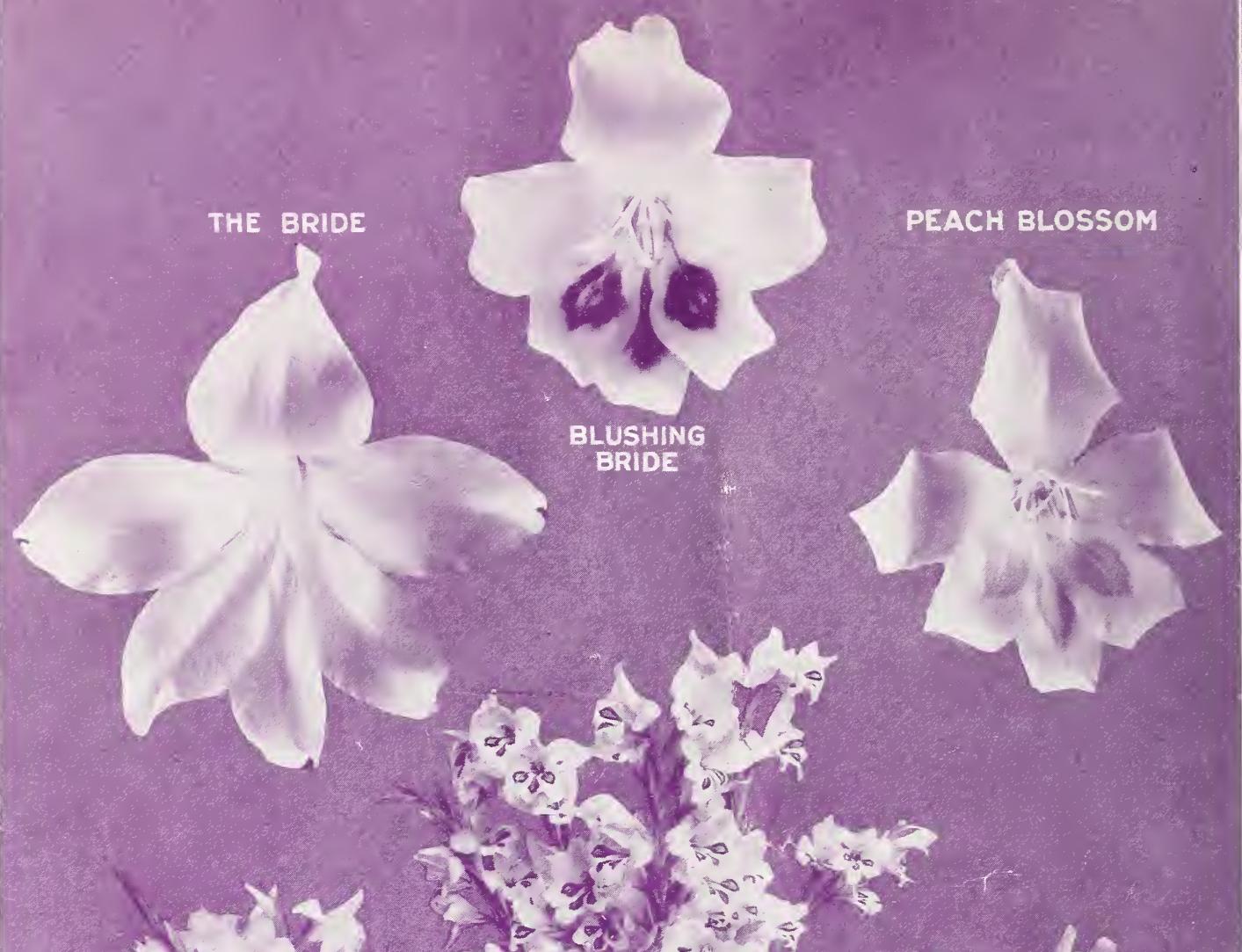

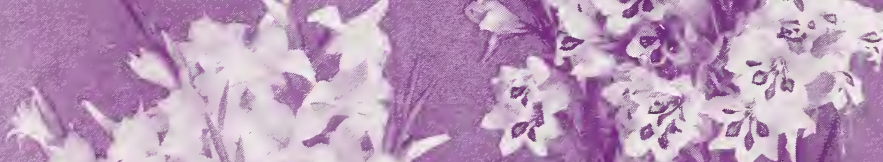
1)

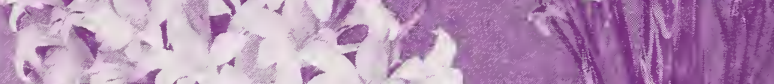
$\sin +x^{2} x^{2}$ $a^{2}+x^{2}$
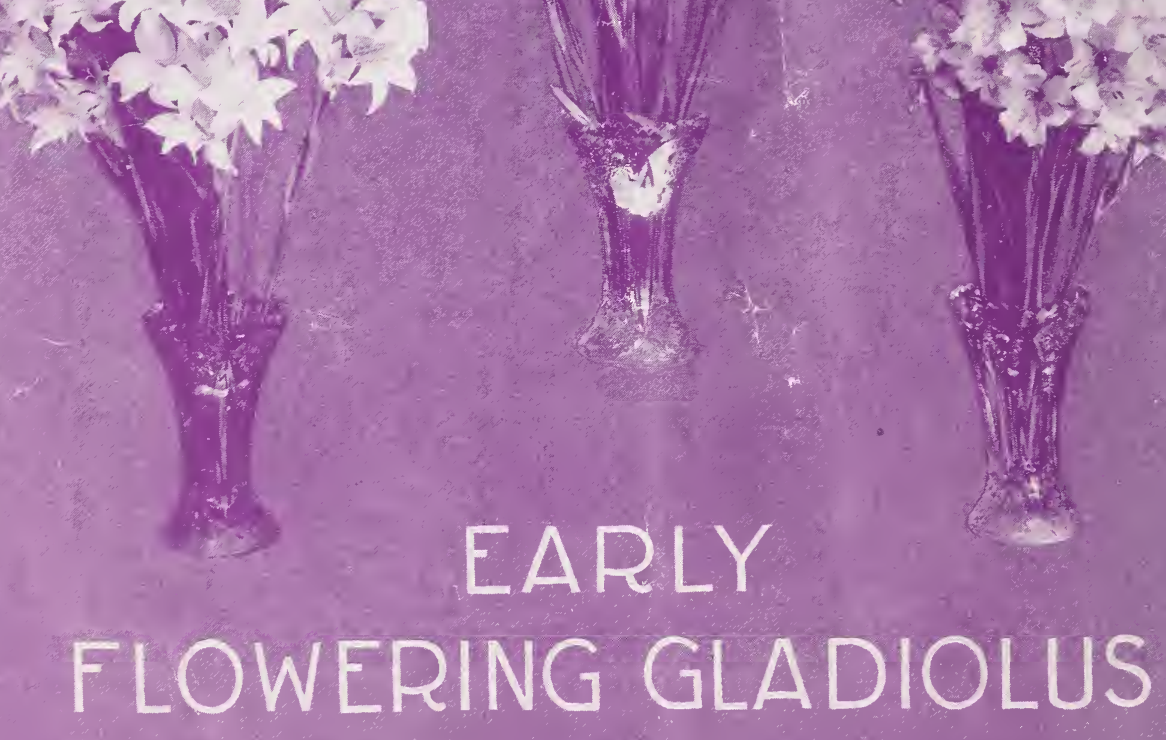